\title{
Dab1 Is Required for Synaptic Plasticity and Associative Learning
}

\author{
Justin Trotter, ${ }^{1 \star}$ Gum Hwa Lee, ${ }^{2 \star}$ Tatiana M. Kazdoba, ${ }^{2,3}$ Beth Crowell, ${ }^{2}$ Jason Domogauer, ${ }^{2}$ Heather M. Mahoney, ${ }^{1}$ \\ Santos J. Franco, ${ }^{4}$ Ulrich Müller, ${ }^{4}$ Edwin J. Weeber, ${ }^{1}$ and Gabriella D’Arcangelo ${ }^{2}$ \\ ${ }^{1}$ Department of Molecular Pharmacology and Physiology, USF Health Byrd Alzheimer's Institute, University of South Florida, Tampa, Florida 33613, \\ ${ }^{2}$ Department of Cell Biology and Neuroscience and ${ }^{3}$ Graduate Program in Neuroscience, Rutgers, The State University of New Jersey, Piscataway, New \\ Jersey 08854, and ${ }^{4}$ Department of Molecular and Cellular Neuroscience, Dorris Neuroscience Center, The Scripps Research Institute, La Jolla, California \\ 92037
}

Disabled-1 (Dab1) is an adaptor protein that is an obligate effector of the Reelin signaling pathway, and is critical for neuronal migration and dendrite outgrowth during development. Components of the Reelin pathway are highly expressed during development, but also continue to be expressed in the adult brain. Here we investigated in detail the expression pattern of Dab1 in the postnatal and adult forebrain, and determined that it is expressed in excitatory as well as inhibitory neurons. Dab1 was found to be localized in different cellular compartments, including the soma, dendrites, presynaptic and postsynaptic structures. Mice that are deficient in Dab1, Reelin, or the Reelin receptors ApoER2 and VLDLR exhibit severely perturbed brain cytoarchitecture, limiting the utility of these mice for investigating the role of this signaling pathway in the adult brain. In this study, we developed an adult forebrain-specific and excitatory neuron-specific conditional knock-out mouse line, and demonstrated that Dab1 is a critical regulator of synaptic function and hippocampal-dependent associative and spatial learning. These dramatic abnormalities were accompanied by a reduction in dendritic spine size, and defects in basal and plasticity-induced Akt and ERK1/2 signaling. Deletion of Dab1 led to no obvious changes in neuronal positioning, dendrite morphology, spine density, or synaptic composition. Collectively, these data conclusively demonstrate an important role for Reelin-Dab1 signaling in the adult forebrain, and underscore the importance of this pathway in learning and memory.

\section{Introduction}

Disabled-1 (Dab1) is an adaptor protein that is essential for neuronal migration and maturation in response to the extracellular protein Reelin (for review, see D'Arcangelo, 2005). Spontaneous mutant mice lacking Reelin (reeler) or Dab1 (scrambler), and Dab1 knock-out (KO) mice present with widespread defects in cellular layer formation (D'Arcangelo et al., 1995; Howell et al., 1997, 2000; Sheldon et al., 1997). A developmental delay in dendrite and axon branching, as well as spine formation and synaptogenesis, has been also reported in the hippocampus of Reelin and Dab1 mutant mice (Del Río et al., 1997; Niu et al., 2004, 2008; Borrell et al., 2007). Reelin signaling continues to perform an important role in the adult brain by promoting excitatory syn-

Received May 10, 2013; revised Aug. 26, 2013; accepted Aug. 29, 2013.

Author contributions: E.J.W. and G.D. designed research; J.T., G.H.L., T.M.K., B.C., J.D., and H.M.M. performed research;S.J.F. and U.M. contributed unpublished reagents/analytic tools;J.T., G.H.L., and T.M.K. analyzed data; G.D. wrote the paper.

This work was supported by Research Grant 10-409-SCH-E-0 from the New Jersey Governor's Council for Medical Research and Treatment of Autism (G.D.), 5R01AG035379-03 Grant from National Institutes of Health/National Institute on Aging (E.J.W.), a Rutgers University Bevier Fellowship (T.M.K.), and Anne B. and James B. Leathem Summer Research Awards (G.H.L. and T.M.K.). We thank A. Goffinet and B. Howell for Dab1 antibodies and J. Cooper for Dab1 knock-out mice. We also appreciate technical assistance from J. Cohen, X. Wang, W.L. Tong, A. Lussier, and E. Donaldson.

*J.T. and G.H.L. contributed equally to this study.

Correspondence should be addressed to Dr. Gabriella D'Arcangelo, Department of Cell Biology and Neuroscience, Rutgers, The State University of New Jersey, Piscataway, NJ 08854. E-mail: darcangelo@biology.rutgers.edu.

DOI:10.1523/JNEUROSCI.2010-13.2013

Copyright $\odot 2013$ the authors $\quad 0270-6474 / 13 / 3315652-17 \$ 15.00 / 0$ apse maturation (Qiu and Weeber, 2007; Ventruti et al., 2011) and modulating synaptic plasticity and learning and memory (Weeber et al., 2002; Pujadas et al., 2010; Rogers et al., 2011).

During forebrain development, Reelin is secreted by CajalRetzius cells in superficial cortical layers (D'Arcangelo et al., 1995; Ogawa et al., 1995), and targets principal neurons, which express apolipoprotein E receptor 2 (ApoER2) and very low density lipoprotein receptor (VLDLR; D’Arcangelo et al., 1999; Hiesberger et al., 1999). Receptor binding leads to the activation of Src family kinases (SFKs) and tyrosine phosphorylation of Dab1 (Hiesberger et al., 1999; Howell et al., 1999). Phosphorylated Dab1 propagates Reelin signaling, regulating neuronal migration through the recruitment of Crk/CrkL (Chen et al., 2004; Park and Curran, 2008), Rap 1, cadherins, and integrin $\alpha 5 \beta 1$ (Franco et al., 2011; Jossin and Cooper, 2011; Sekine et al., 2012). The molecular mechanism underlying the control of postnatal developmental processes, such as dendrite outgrowth and spine formation, also requires ApoER2/VLDLR and Dab1 (Niu et al., 2004, 2008) and the downstream activity of phosphatidylinositol-3 kinase (PI3K)/Akt (Beffert et al., 2002) and mTOR (Jossin and Goffinet, 2007).

In the adult forebrain, Reelin is secreted by a subset of inhibitory neurons (Alcántara et al., 1998; Pesold et al., 1998), and it is believed to be important for synaptic function since Reelin haploinsuffiency or loss of either VLDLR or ApoER2 leads to learning and memory deficits (Weeber et al., 2002; Qiu et al., 2006b). However, at least one study did not report similar defects in 
heterozygous reeler mice (Krueger et al., 2006). An ApoER2 isoform capable of binding postsynaptic density (PSD)- 95 has been further implicated in synaptic plasticity and cognition through a mechanism involving the NMDA receptor (NMDAR; Beffert et al., 2005). The role of Dab1 in the adult brain has not yet been investigated due to the absence of an animal model that lacks developmental abnormalities. To overcome this limitation, we generated a conditional $\mathrm{KO}(\mathrm{cKO})$ mouse with selective deletion of Dab1 in excitatory neurons of the adult forebrain. Here we present evidence that Dab1 plays a critical role in mediating the synaptic function of Reelin, and that it is required for hippocampal synaptic plasticity and learning and memory.

\section{Materials and Methods}

\section{Mouse colonies}

All animals used for this study were handled in accordance with protocols approved by the Association for Assessment and Accreditation of Laboratory Animal Care committee at Rutgers, The State University of New Jersey, and by the Institutional Animal Care and Use Committee of the University of South Florida. Animals of either sex were group housed in a standard $12 \mathrm{~h}$ light/dark cycle and fed ad libitum standard mouse chow. The Dab1 $1^{\text {flox/flox }}$ founder mice were genotyped as described previously (Franco et al., 2011). CaMKII $\alpha$-Cre transgenic driver mice (B6.Cg-Tg(Camk2a-cre)T29-1Stl/J), tdTomato reporter mice (B6.Cg-Gt(ROSA)26Sor $\left.{ }^{\text {tm } 9(C A G-t d T o m a t o) H z e} / \mathrm{J}\right), \quad$ spontaneous Dab1 mouse mutant scrambler (A/A-Dab $\left.1^{\mathrm{scm}} / \mathrm{J}\right)$, and wild-type C57BL6 mice were obtained from The Jackson Laboratory. Mutant and transgenic mice were genotyped by PCR as suggested by the distributor. Constitutive Dab1 KO mice were obtained from J. A. Cooper (Fred Hutchinson Cancer Research Center, Seattle, WA) and genotyped as described previously (Howell et al., 1997).

\section{Tissue histology and immunostaining}

Mice were deeply anesthetized with Avertin (2,2,2-tribromoethanol dissolved in tertiary amyl alcohol and distilled water) or isoflurane and perfused transcardially with PBS ( $\mathrm{pH} 7.2)$ or saline solution $(0.9 \%$ $\mathrm{NaCl}$ ), followed by $4 \%$ paraformaldehyde (PFA) in PBS. Brains were dissected, postfixed in $4 \%$ PFA overnight at $4^{\circ} \mathrm{C}$, and cryoprotected by incubation at $4^{\circ} \mathrm{C}$ in $30 \%$ sucrose in PBS. Brains were mounted onto a sliding microtome using OCT (Tissue-Tek) and sectioned either coronally (for immunohistochemistry) or sagittally (for histology) at 25-30 $\mu \mathrm{m}$. To evaluate neuroanatomical organization, sections were processed for thionin staining (FD Neurotechnologies) according to the manufacturer's protocol.

For immunoperoxidase staining, brain sections were immersed in 3\% $\mathrm{H}_{2} \mathrm{O}_{2}$ solution for $15 \mathrm{~min}$ at room temperature (RT). Sections were washed with PBS and then permeabilized and blocked with $4 \%$ normal goat serum (NGS) in PBS (supplemented with $1.83 \%$ lysine and $0.2 \%$ Triton X-100) for $30 \mathrm{~min}$ at RT. Sections were incubated overnight at RT with anti-Dab1 B3 antibody at 1:1000 (provided by Dr. Brian Howell, SUNY Upstate Medical University) diluted in PBS with $0.2 \%$ Triton X-100 and 4\% NGS. After washing with PBS, sections were incubated with biotinylated goat anti-rabbit IgG (1:3000; Southern Biotech) diluted in PBS with $0.2 \%$ Triton X-100 and 4\% NGS. Sections were washed in $\mathrm{PBS}$ and then incubated with $\mathrm{ABC}$ reagent (Vectashield) for $1 \mathrm{~h}$ at RT, followed by three washes in PBS and one wash in fresh TBS. Sections were incubated with $1.4 \mathrm{~mm}$ diaminobenzidine in Tris-buffered saline (TBS) with $0.03 \%$ hydrogen peroxide and $0.5 \%$ nickel ammonium sulfate in PBS for 5 min. Finally, stained sections were mounted on positively charged glass slides, dehydrated, and coverslipped with DPX mounting media. Imaging was performed with a Zeiss Axio Scope A1 Microscope. Fluorescence immunostaining was performed as described previously (Trotter et al., 2011). The following primary antibodies were used: antiDab1 B3 (1:500), anti-Reelin (1:1000; MAB5364, Millipore), anti-NeuN (1:2000; MAB377, Millipore), anti-PSD-95 (1:2000; P78352, NeuroMab), anti-synaptophysin (1:400; 5461, Cell Signaling Technology), and anti-GAD67 (1:2000; MAB5406, Millipore). The following secondary antibodies were used: goat anti-mouse IgG-Alexa 546, goat anti-rabbit
IgG-Alexa 488, and goat anti-rabbit IgG-Alexa 633 (all used at 1:500 and obtained from Invitrogen). Sections were mounted on positively charged glass slides and coverslipped with ProLong Gold Antifade Reagent with DAPI (Invitrogen). Sections were imaged using the Olympus FV10i confocal microscope. For comparison between genotypes; images were taken with the same exposure settings and were adjusted similarly for brightness and contrast in Adobe Photoshop.

\section{Protein extracts and crude synaptosome preparation}

For developmental analysis, the cortex, hippocampus, and cerebellum were dissected from C57BL6 mice at several postnatal days and snap frozen. The cortices and hippocampi of homozygous constitutive Dab1 $\mathrm{KO}$ mice or Dab1 cKO mice and their wild-type (WT) littermates were dissected and processed for total lysates or synaptoneurosome (SNS) fractions. Frozen cell pellets from primary neuronal cultures or hippocampal slices were similarly processed for total lysate extraction. All centrifugation steps were performed at $4^{\circ} \mathrm{C}$. To prepare total lysates, the tissue or cell pellets were homogenized in ice-cold radioimmunoprecipitation assay buffer (50 mM Tris, pH 7.4, 1\% NP40, 0.25\% sodium deoxycholate, $150 \mathrm{~mm} \mathrm{NaCl}, 1 \mathrm{~mm}$ EGTA) supplemented with complete protease and phosphatase inhibitor cocktails and cleared by centrifugation at $15,000 \times g$ for $10 \mathrm{~min}$ at $4^{\circ} \mathrm{C}$. SNS fractions were prepared as described previously with minor modifications (Hoe et al., 2009; Ventruti et al., 2011). Tissue was homogenized in ice-cold homogenization buffer ( 5 mM HEPES, pH 7, $1 \mathrm{~mm} \mathrm{MgCl}_{2}, 0.5 \mathrm{~mm} \mathrm{CaCl}_{2}$ ) containing protease inhibitor and phosphatase inhibitor as mentioned above. The total homogenate was centrifuged at $1500 \times g$ for $10 \mathrm{~min}$ and the supernatant (S1) was collected. The pellet was resuspended in homogenization buffer and centrifuged again at $800 \times g$ for $10 \mathrm{~min}$. The supernatant was collected, combined with S1, and cleared by centrifugation at $13,800 \times g$ for $10 \mathrm{~min}$ to obtain the homogenate sample. The remaining pellet, containing SNS fraction, was resuspended in homogenization buffer. Synaptic fractionation was performed on freshly dissected forebrains from 3-month-old C57BL6 mice as described previously (Dumanis et al., 2011).

\section{Western blot analysis}

For brain tissue analysis, protein concentration was determined using the Bradford or BCA Protein Assay (Bio-Rad or Thermo Scientific). Samples were adjusted to equal protein concentration and combined with Laemmli Sample Buffer containing 5\% 2-mercaptoethanol. Samples were boiled for $5 \mathrm{~min}$ at $95^{\circ} \mathrm{C}$, except when analyzing Reelin expression. Protein lysates were separated electrophoretically onto $8 \%$ or $4-15 \%$ Trisglycine SDS-PAGE gels (Invitrogen or Bio-Rad) and transferred to nitrocellulose or PVDF blotting membrane. The membranes were blocked in a solution containing $0.1 \mathrm{~m}$ TBS with $0.1 \%$ Tween 20 and 5\% nonfat milk, and then incubated overnight at $4^{\circ} \mathrm{C}$ with primary antibodies diluted in blocking solution. Primary antibodies include: monoclonal anti-Dab1 (a gift from Dr. André M Goffinet, Université Catholique de Louvain, Belgium), anti-p-Akt (Ser473; \#3787, Cell Signaling Technology), anti-total Akt (\#2966, Cell Signaling Technology), anti-p-ERK1/2 (Thr202/Tyr204; \#4370, Cell Signaling Technology), anti-total ERK1/2 (\#4696, Cell Signaling Technology), anti-NR2A (\#07-632, Millipore), anti-NR2B (\#06-600, Millipore), anti-NR1 (\#05-432, Millipore), antisynapsin IIa (\#610667, BD Transduction labs), anti-ribosomal protein S6 (\#2317, Cell Signaling Technology), anti-PSD-95 (P78352, NeuroMab), anti-synaptophysin (\#5461, Cell Signaling Technology), anti-Reelin (MAB5364, Millipore), anti-ApoER2 (ab108208, Abcam), anti-GADPH (H86903M, Meridian Life Science), and anti- $\beta$-actin (\#4967, Cell Signaling Technology). The next day, membranes were washed and incubated with anti-mouse IgG-horseradish peroxidase (HRP) or anti-rabbit IgGHRP secondary antibodies (Sigma or Southern Biotech) diluted at 1:2000 in blocking solution. Proteins were detected using Pierce ECL Western Blotting Substrate (Thermo Scientific) and autoradiography. The films were digitized and optical densities were measured using a computerized image analysis system with a high-powered scanner and the software program ImageJ (v1.43u, National Institutes of Health) or Alphaimager (ProteinSimple). 


\section{Golgi impregnation}

Golgi-Cox impregnation was performed by FD Neurotechnologies, using the GD Rapid Golgi Stain Kit (\#PK401). Briefly, Dab1 cKO and WT controls were perfused for 5 min with PBS, followed by 4\% PFA in PBS for $15 \mathrm{~min}$. Brains were immersed in impregnation solution (equal volumes of Solutions A and B, containing mercuric chloride, potassium dichromate, and potassium chromate), and stored at room temperature. Impregnation solution was replaced after $24 \mathrm{~h}$. After 2 weeks, brains were transferred to Solution C and stored at $4^{\circ} \mathrm{C}$ for $48 \mathrm{~h}$, with the solution replaced after $24 \mathrm{~h}$. The brain was sectioned sagittally at $100 \mu \mathrm{m}$ using a cryostat and sections were mounted on gelatin-coated microscope slides with Solution C. Slides were rinsed twice in distilled water (2 min each), and then placed in a mixture of one part Solution D, one part Solution E, and two parts distilled water for $10 \mathrm{~min}$. After rinsing with distilled water, sections were dehydrated in 50\%, 75\%, and 95\% ethanol (4 min each), and then were further dehydrated in $100 \%$ ethanol four times (4 min each). Sections were cleared in xylene three times (4 min each) and coverslipped with Permount solution.

\section{Dendrite and spine analysis}

Comparable Golgi-stained sections obtained from WT and Dab1 cKO mice were imaged by an experimenter blinded with respect to genotype. To examine the dendrite branching pattern of hippocampal pyramidal neurons in area CA1, $z$-stack bright-field images were collected at $1 \mu \mathrm{m}$ increments using an inverted microscope (Olympus IX50) with $10 \times$ and $20 \times$ objectives. The images were then flattened, and the number of secondary apical branches was measured. To determine the orientation of apical dendrites and the soma, the shortest line between hippocampal surfaces was drawn, and the angle between this line and the longest axis corresponding to either the primary apical dendrite or the soma was measured as described previously (O'Dell et al., 2012). A total of 26 WT and $17 \mathrm{cKO}$ neurons from 4 to 5 animals of each genotype were traced for dendrite analysis and $40 \mathrm{WT}$ and $34 \mathrm{cKO}$ neurons for soma analysis. For spine analysis, secondary apical dendrites in the stratum radiatum of the CA1 region were imaged in bright field with a $60 \times$ Plan Apo oilimmersion objective (NA 1.4). $z$-Stack images were generated at $0.2 \mu \mathrm{m}$ increments. Dendrite length was traced through the $z$-stack using the open source Simple Neurite Tracer, a Segmentation Plugin in ImageJ (FIJI image processing package). The number of dendritic spines was quantified from multiple dendrite segments, and spine density values were averaged by the number of neurons analyzed (WT $=46$ neurons; $\mathrm{cKO}=57$ neurons). Data were obtained from multiple brain sections per animal (4-5 animals per genotype). A subset of $z$-stack images was randomly selected and further used to analyze dendritic spine area. Dendritic spine area $\left(\mu \mathrm{m}^{2}\right)$ was measured using a $4 \times$ digital zoom and the Freehand Selection Tool in ImageJ. Data were averaged by neuron $(n=$ 50 neurons per genotype). Dendritic spine density and area analyses were performed by an experimenter blinded with respect to genotype.

\section{Ex vivo slice preparation and chemical long-term potentiation induction}

Hippocampal slices were prepared from 2-month-old Dab1 cKO and WT controls as described previously (Weeber et al., 2002). Briefly, brains were sectioned horizontally in ice-cold cutting solution at $400 \mu \mathrm{m}$. The hippocampus was dissected and acclimated in 50:50 solution (cutting: artificial CSF (ACSF)) for $10 \mathrm{~min}$ at room temperature. Sections were then recovered in $\mathrm{ACSF}$ at $32^{\circ} \mathrm{C}$ for $2 \mathrm{~h}$. Chemical long-term potentiation (cLTP) was induced by exposing slices to tetraethylammonium chloride (TEA-Cl, $25 \mathrm{~mm}$ ) diluted in ACSF (adjusted for osmolarity) for $10 \mathrm{~min}$. Slices were recovered in normal ACSF and collected at 5 and $45 \mathrm{~min}$ post-treatment. Hippocampal area CA1 was rapidly removed under a dissecting microscope and snap frozen until further analysis.

\section{Electrophysiology}

Hippocampus slices were prepared from 3- to 6-month-old Dab1 cKO and WT mice as previously reported (Weeber et al., 2002). The brain was rapidly dissected and placed in ice-cold, oxygenated cutting solution containing (in mM): 110 sucrose, $60 \mathrm{NaCl}, 3 \mathrm{KCl}, 28 \mathrm{NaHCO}_{3}, 1.25$ $\mathrm{NaH}_{2} \mathrm{PO}_{4}, 5$ glucose, 0.6 ascorbate, $7 \mathrm{MgCl}_{2}$, and $0.5 \mathrm{CaCl}_{2}$. Horizontal $350 \mu \mathrm{m}$ sections were generated in cutting solution using a vibratome.
The hippocampus was carefully dissected and transferred to room temperature cutting solution diluted 1:1 with ACSF containing (in $\mathrm{mm}$ ): $125 \mathrm{NaCl}, 2.5 \mathrm{KCl}, 26 \mathrm{NaHCO}_{3}, 1.25 \mathrm{NaH}_{2} \mathrm{PO}_{4}, 25$ glucose, $1 \mathrm{MgCl}_{2}$, and $2 \mathrm{CaCl}_{2}$. Slices were maintained in this solution with constant $95 \%$ $\mathrm{O}_{2} / 5 \% \mathrm{CO}_{2}$ perfusion for $10 \mathrm{~min}$ before being transferred to the brain slice recording chamber (Fine Science Tools) or maintained in a holding container. Slices were recovered for a minimum of $1 \mathrm{~h}$ before recording. The recording chamber was held at $30^{\circ} \pm 0.5^{\circ} \mathrm{C}$ with a ACSF flow rate of $1 \mathrm{ml} / \mathrm{min}$. Field EPSPs (fEPSPs) were recorded from stratum radiatum in hippocampal area CA1 via glass micropipettes pulled to an approximate $1 \mu \mathrm{m}$ tip diameter (1-4 M $\Omega$ ) and loaded with ACSF. Responses were generated by stimulation of Schaffer collaterals arising from the CA3 region. Stimulating electrodes consisted of formvar-coated nichrome wire, which was used to deliver biphasic stimulus pulses $(1-15 \mathrm{~V}, 100 \mu \mathrm{s}$ duration, $0.05 \mathrm{~Hz}$ ). Delivery of stimulation, controlled by pClamp 9.0 software (Molecular Devices), was via the Digidata 1322A interface (Molecular Devices) and a stimulus isolator (model 2200; A-M Systems). Signals were amplified using a differential amplifier (model 1800; A-M Systems), filtered at $1 \mathrm{kHz}$, and digitized at $10 \mathrm{kHz}$. For all experiments, baseline stimulus intensity was set at the level that elicited $\sim 50 \%$ of the maximum fEPSP response as determined from the input-output curve. The input-output relationship was determined by stimulating slices from 0 to $18 \mathrm{mV}$ at $0.5 \mathrm{mV}$ increments. Short-term plasticity was measured via paired-pulse facilitation (PPF), which was induced by stimulating slices at half-max intensity with sequential pulses spaced at $20 \mathrm{~ms}$ intervals from 20 to $300 \mathrm{~ms}$. LTP was induced by a theta-burst protocol, which consisted of five trains of four pulse bursts at $200 \mathrm{~Hz}$ separated by $200 \mathrm{~ms}$, repeated six times with an intertrain interval of $10 \mathrm{~s}$. Highfrequency stimulation (HFS) was also used to induce LTP, comprising two $1 \mathrm{~s}$ trains of $100 \mathrm{~Hz}$ stimulation with a $20 \mathrm{~s}$ intertrain interval. To evaluate Reelin's effects on theta burst-induced LTP, slices were bathed with $5 \mathrm{~nm}$ Reelin or Mock conditioned media for $10 \mathrm{~min}$ before LTP induction. For analysis, the last 10 min of recording was averaged and compared.

\section{Mouse behavior}

WT ( 5 males, 6 females) and Dab1 cKO mice ( 5 males, 6 females) at 3 to 6 months of age were subjected to behavioral studies. No sexual dimorphism of phenotype was observed.

Associative fear conditioning. Fear conditioning was used to assess hippocampus function and associative learning and memory. Mice were placed in a $25 \times 25 \mathrm{~cm}$ sound attenuation chamber with a wire grid floor and allowed to explore the context for $3 \mathrm{~min}$. They then received a conditioned stimulus (CS; $90 \mathrm{db}$ tone) for $30 \mathrm{~s}$. At the end of the $30 \mathrm{~s}$, mice received a mild footshock (0.5 $\mathrm{mA}$ : unconditioned stimulus (US)) that coterminated with the tone. After $1.5 \mathrm{~min}$, the mice received a second CS/US pairing, after which monitoring continued for $1.5 \mathrm{~min}$. For the context test, $24 \mathrm{~h}$ following CS/US pairing mice were placed back into the chamber and allowed to explore for $3 \mathrm{~min}$. Mice were then subjected to the cued test, which required placing mice in a novel context (new noise, smells, textured surfaces, etc.) for a 3 min exploratory period followed by a $3 \mathrm{~min}$ exposure to the CS. An investigator blind to genotype monitored the mice and scored freezing at $5 \mathrm{~s}$ intervals throughout the testing session.

Hidden platform water maze. A $1.2 \mathrm{~m}$ diameter pool was filled with white opaque water and a $10 \mathrm{~cm}$ diameter white platform was submerged just below the water surface. Large extra-maze cues were positioned around the room. During a single trial, mice were placed in the pool and allowed to swim to the escape platform for a maximum of $60 \mathrm{~s}$. Mice were given four trials per day for $4 \mathrm{~d}$. Latency to escape, distance traveled, and swim speed were measured by video tracking software (ANY-Maze; Stoelting). At 24 and $72 \mathrm{~h}$ following training day 4, the platform was removed and swim patterns were monitored for $60 \mathrm{~s}$ during a probe trial.

Open-field test. General activity and anxiety were measured by the open-field test. Mice were placed in a $40 \times 40 \mathrm{~cm}$ acrylic chamber under normal lighting conditions and allowed to explore for $30 \mathrm{~min}$. Video tracking software monitored movement, immobility, and distance traveled (ANY-Maze; Stoelting). Anxiety was measured by comparing the amount of time spent in the center versus wall quadrants of the open 
A

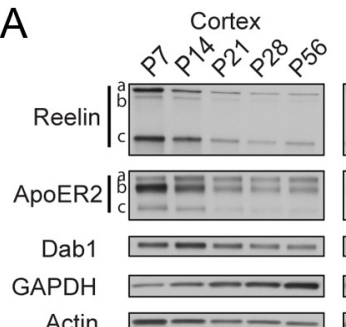

Actin

C
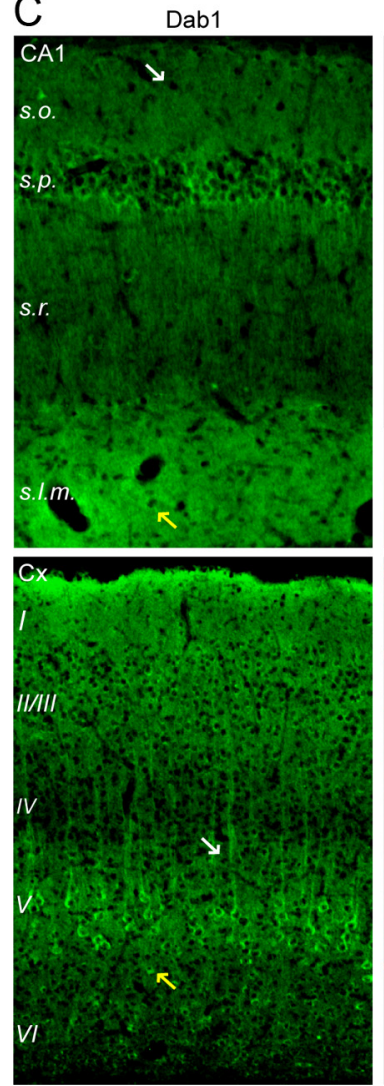

Hippocampus
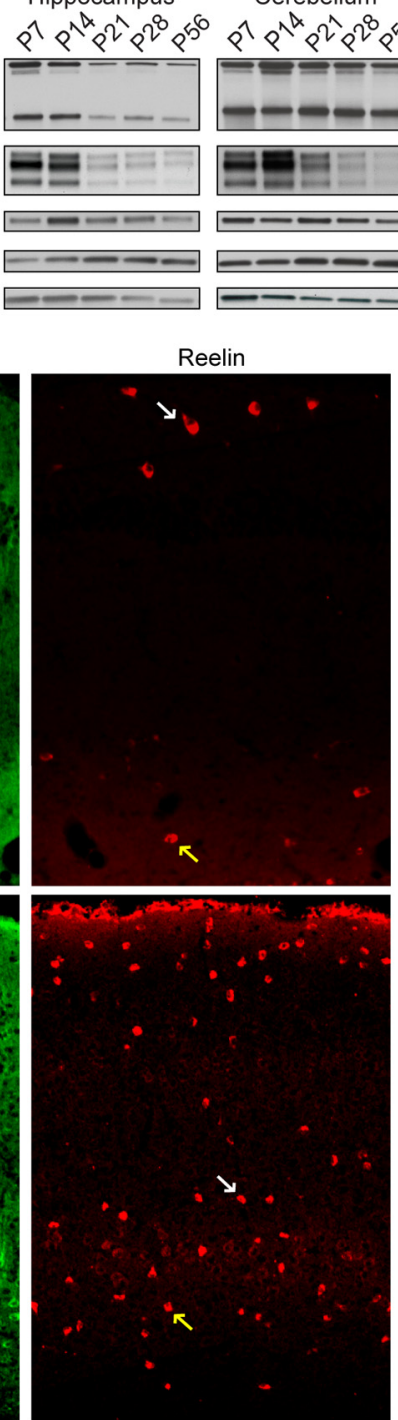

Cerebellum

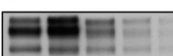

$-\infty-$

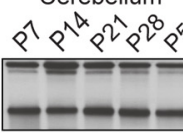

$--$
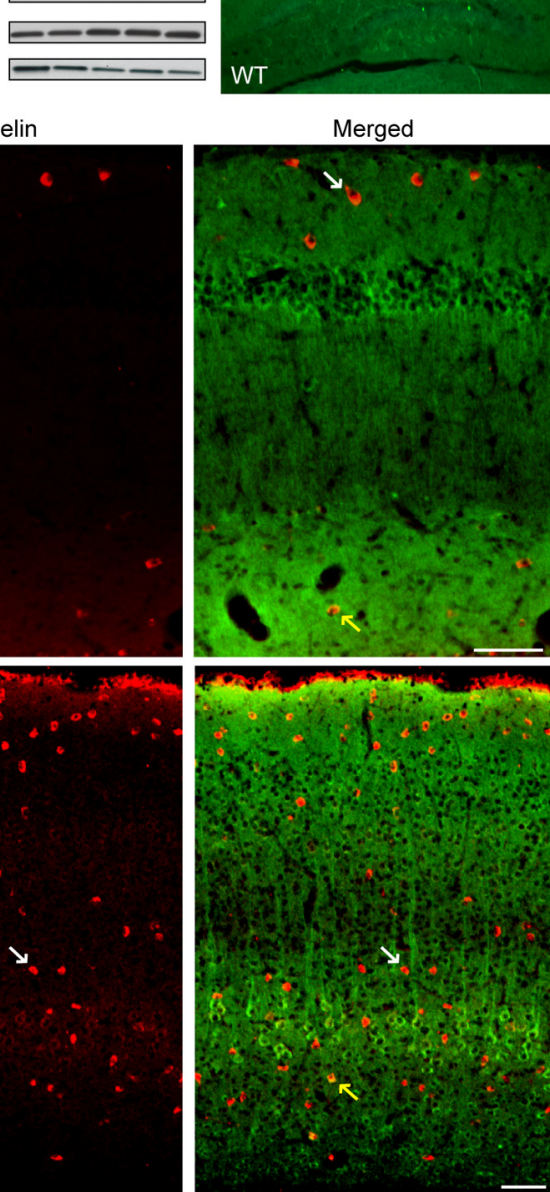

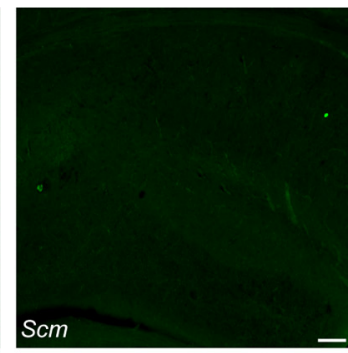

D
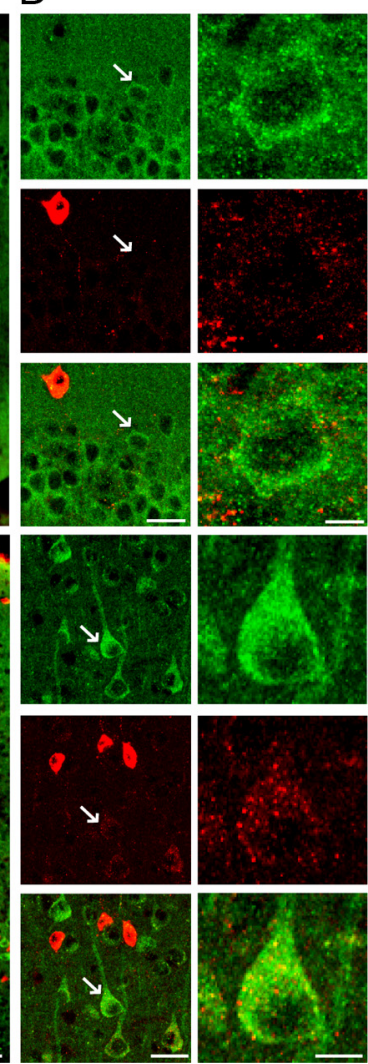

Figure 1. Dab1 and Reelin expression in the postnatal forebrain. A, Western blot analysis of Reelin, ApoER2, and Dab1 in the cortex, hippocampus, and cerebellum at P7, P14, P21, P28, and P56. Blots shown are representative of data obtained from 3 to 4 mice per age. Reelin was detected as a full-length isoform of $\sim 450 \mathrm{kDa}$ (a) and two N-terminal fragments of 370 (b) and $180 \mathrm{kDa}$ (c). ApoER2 was detected as three major isoforms (a, b, c). Dab1 was detected as a single band of $\sim 90 \mathrm{kDa}$. The blots were reprobed with GAPDH and actin antibodies as loading controls. $\boldsymbol{B}$, Immunofluorescence labeling of Dab1 in the postnatal hippocampus. Dab1 signal (green) was present in WT examples, but not in the Dab1 mutant scrambler ( $\mathrm{Scm}$ ), confirming antibody specificity. Scale bar, $100 \mu \mathrm{m}$. C, D, Double immunofluorescence labeling of hippocampal area CA1 and the neocortex (CX) with Dab1 (green) and Reelin (red) antibodies. Sections were obtained from 2- to 3-month-old WT mice. Larger panels show Dab1 and Reelin staining in mostly distinct cell populations (white arrows), with the exception of a few cells that showed colocalization (yellow arrows). $\boldsymbol{D}$, Smaller panels show Dab1 labeling at higher magnification (left, white arrows). Scale bars: $\boldsymbol{B}$ and $\boldsymbol{C}, 100 \mu \mathrm{m}$; $\boldsymbol{D}$, left, $20 \mu \mathrm{m}$; right, $10 \mu \mathrm{m}$.

field. Data were binned into 5 min intervals to evaluate time-dependent differences in locomotor activity.

Statistical analysis. Data in bar graphs are shown as the mean \pm SEM, and analyzed by Student's $t$ test, one-sample $t$ test, or ANOVA as indicated in the results. The Bonferroni post hoc test was used for both oneway and two-way ANOVA tests. Statistical significance was determined when $p<0.05$.

\section{Results}

Expression pattern of Dab1 and other components of the Reelin pathway in the postnatal forebrain

Reelin signaling through ApoER2/VLDLR and Dab1 is critical for several aspects of brain development, including neuronal positioning (D'Arcangelo et al., 1995; Sheldon et al., 1997; Trommsdorff et al., 1999), dendritic morphogenesis (Niu et al., 2004), and the formation and maturation of excitatory synapses (Liu et al., 2001; Groc et al., 2007; Qiu and Weeber, 2007; Niu et al., 2008;
Ventruti et al., 2011). In the adult brain, Reelin signaling has been implicated in hippocampal synaptic plasticity, and learning and memory (Weeber et al., 2002; Beffert et al., 2005; Qiu et al., 2006b). To further investigate the adult function of Reelin signaling, we first examined how the expression of Reelin and its signaling molecules transitions from a developmental to an adult pattern. We collected brain samples ranging from postnatal day (P7) to adulthood (P56), and conducted Western blot analysis of Reelin, ApoER2, and Dab1 in the cerebral cortex, hippocampus, and cerebellum. All three proteins were readily detected in the developing and adult structures examined (Fig. 1A). The expression of Reelin and its proteolytic fragments was highest at approximately P7 in forebrain structures, and declined rapidly with age. In the cerebellum, Reelin expression peaked at approximately P14, but remained elevated even during adulthood. The shifted pattern of Reelin expression in the cerebellum parallels 
the delayed development of this structure compared with the forebrain. A similar expression pattern was observed for ApoER2. However, the expression pattern of Dab1 appeared to be delayed compared with Reelin, and remained sustained throughout adulthood in all structures. When normalized to P7 levels, Dab1 levels in the hippocampus and cerebral cortex were highest at P14 (214 \pm 3.5 and $118 \pm 6.8 \%$, respectively) and lowest at P56 $(74.9 \pm 3.1$ and $39.9 \pm 11.8 \%$, respectively). In the cerebellum, Dab1 expression was relatively stable from P7 to P28 (85.2 \pm $4.7 \%$ compared with $\mathrm{P} 7$ levels), but declined to significantly lower levels by P56 (58.6 $\pm 5.3 \%$ compared with P7 levels).

To further examine Dab1 expression in the adult forebrain, we conducted immunofluorescence staining using the previously described Dab1 B3 antibody (Howell et al., 1997). We first verified the specificity of the antibody by staining brain tissue sections obtained from adult Dabl-deficient scrambler $(\mathrm{Scm})$ mutant mice and WT littermates. Dab1 was detected prominently throughout the forebrain of WT mice, but not $\mathrm{Scm}$ mutants (Fig. 1B). In the WT hippocampus, the Dab1 signal appeared to be widespread and diffuse, and particularly intense in cell bodies of the pyramidal layer, and in the neuropil of the stratum lacunosum moleculare (s.l.m.; Fig. $1 C, D$ ). In the neocortex, the Dab1 signal was high in the cell bodies and apical dendrites of many pyramidal neurons, particularly the large pyramidal neurons of layer $\mathrm{V}$, and in the neuropil of the marginal zone (layer I). Double labeling with Reelin antibodies indicated that this protein is highly expressed in a few isolated cells, which are located predominantly in the stratum oriens (s.o.) and s.l.m. of the hippocampus, and in all cellular layers of the neocortex (Fig. 1C,D). These findings are consistent with previous reports, which demonstrated that Reelin is expressed by a subset of GABAergic interneurons and residual Cajal-Retzius cells in the postnatal forebrain (Alcántara et al., 1998). When images of Dab1 and Reelin staining are overlaid, it is apparent that these two proteins are expressed mostly in nonoverlapping cell populations, as previously reported in the prenatal brain (Rice et al., 1998). Occasionally, however, Dab1 was coexpressed in the cell body of a small fraction of Reelin-positive cells in both the cortex and hippocampus (Fig. 1C, yellow arrows). Diffuse Reelin and Dab1 signals colocalized extensively in the s.l.m. of area CA1 (Fig. $1 C)$, a region where the distal apical dendrites of Dab1-expressing pyramidal cells come in close proximity to Reelin-secreting $\mathrm{Ca}$ jal-Retzius cells. Very faint and punctate Reelin immunoreactivity was also observed on Dab1-positive pyramidal cells in cortical layers II/III and V, and to a lesser extent in the hippocampus (Fig. $1 D$, right). It is likely that this signal represents surface-bound and/or internalized Reelin, as has been suggested previously in cortical cultures (Campo et al., 2009). Collectively, these data demonstrate that Reelin- and Dab1-expressing cells remain intimately juxtaposed in the adult forebrain.

\section{Synaptic localization of Dab1 in the adult forebrain}

Because we observed Dab1 expression in the dendrites as well as the soma of pyramidal cells, we next determined whether this protein localizes to synaptic structures in the adult forebrain. Crude SNSs were isolated from the cerebral cortex and hippocampus of 1-month-old mice, and analyzed by Western blotting using Dab1 monoclonal antibodies. Samples obtained from previously described constitutive Dab1 KO mice (Howell et al., 1997) were used to confirm the specificity of the antibody. The data indicate that Dab1 is present at similar levels in the homogenate and SNS fractions of both the cortex and hippocampus. Dab1 SNS levels were $94.5 \pm 8.5 \%$ of homogenate levels in the cortex, and $120.8 \pm 14.2 \%$ of homogenate in the hippocampus ( $p>0.05$; Fig. $2 A$ ), suggesting that a considerable amount of the protein is associated with synapses. To control for the quality of our SNS fractions, we reprobed the blots using antibodies directed against well known synaptic protein markers. As expected, the postsynaptic protein NR1 and presynaptic protein synapsin IIa were enriched in SNS fractions of both the cortex and hippocampus, whereas actin levels were similar among samples (Fig. 2A).

To distinguish between presynaptic and postsynaptic localization of Dab1, further fractionation of synaptic and perisynaptic proteins was performed as described previously (Dumanis et al., 2011). Dab1 was readily detected in the purified synaptic membrane fraction (LP1) at levels comparable to the initial, crude SNS fraction $(\mathrm{P} 2)(95.4 \pm 3.08 \% \mathrm{LP} 1$ normalized to $\mathrm{P} 2, p>0.05$; Fig. $2 B$ ). To allow better visualization of Dab1 and Reelin, total protein levels loaded for the presynaptic vesicle (SV, also known as the LP2 fraction) and the PSD fractions were four times higher than P2 and LP1 fractions. Quantification revealed similar levels of presynaptic and postsynaptic Dab1 (5.93 $\pm 0.85 \% \mathrm{SV}$ and $5.5 \pm 1.18 \%$ PSD normalized to P2 levels; $p>0.05)$. A similar synaptic localization pattern was observed when the same blots were reprobed with Reelin antibodies (Fig. 2B). However, only the full-length (a) and the intermediate isoform of Reelin (b) were detected in synaptic fractions, possibly due to the higher solubility of the fully cleaved $\mathrm{N}$-terminal fragment (c), which was readily detectable in homogenate samples (Fig. $1 A$ ) and soluble fractions (data not shown). To control for the quality of presynaptic and postsynaptic fractions, we reprobed blots with synaptophysin and PSD-95 antibodies. As expected, PSD-95 was detected in the PSD and not in the SV fraction, whereas synaptophysin was detected in the SV and not in the PSD fraction (Fig. 2B).

To further examine Dab1 localization at the synapse, we performed triple immunofluorescence labeling of Dab1, PSD-95, and synaptophysin in adult hippocampal sections and focused on the stratum radiatum (s.r.) of area CA1, where apical dendrites of pyramidal cells receive excitatory inputs from Schaffer collaterals. In this region, Dab1, PSD-95, and synaptophysin were detected in a punctate pattern along dendritic segments (Fig. 2C,D). Although most Dab1-positive puncta did not colabel with both PSD-95 and synaptophysin (Fig. 2D,F), some did, suggesting Dab1 localization to at least some putative excitatory synapses (Fig. 2D,E, yellow circle). Frequent apposition of Dab1- and synaptophysin-positive puncta was also noted in PSD-95-negative clusters (Fig. 2D, white circle, $F$ ), suggesting the possible additional localization of Dab1 to inhibitory synaptic structures.

\section{Generation of cKO mice with excitatory neuron-specific loss of Dab1 in the adult forebrain}

Complete loss of Reelin or Dab1 during development leads to dramatically disrupted neuronal positioning (D'Arcangelo et al., 1995; Sheldon et al., 1997; Trommsdorff et al., 1999), abnormal growth of cellular processes (Del Río et al., 1997; Niu et al., 2004), and altered formation of excitatory synaptic structures (Niu et al., 2008), hindering the study of this molecular pathway in the adult brain. To overcome this limitation, we generated a novel cKO mouse in which the Dab1 gene is specifically deleted in the adult forebrain. Mice carrying floxed Dab1 alleles (Dab1 ${ }^{\text {flox/flox }}$ ) (Franco et al., 2011) were crossed with CaMKII $\alpha$-Cre (T-29) transgenic driver mice (Tsien et al., 1996). This driver line has previously been extensively characterized, and reported to exhibit Cre expression almost exclusively in forebrain structures, 
A

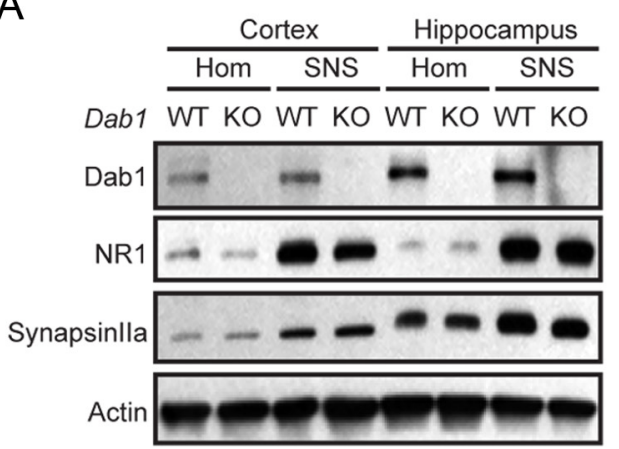

B

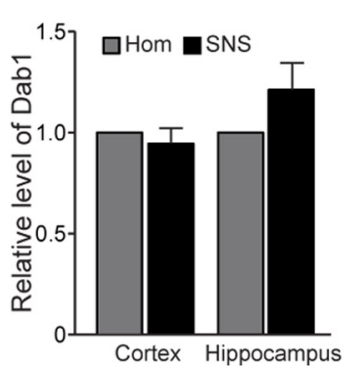

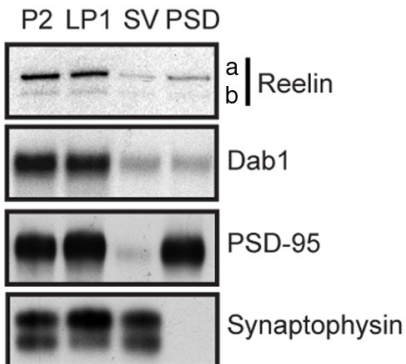
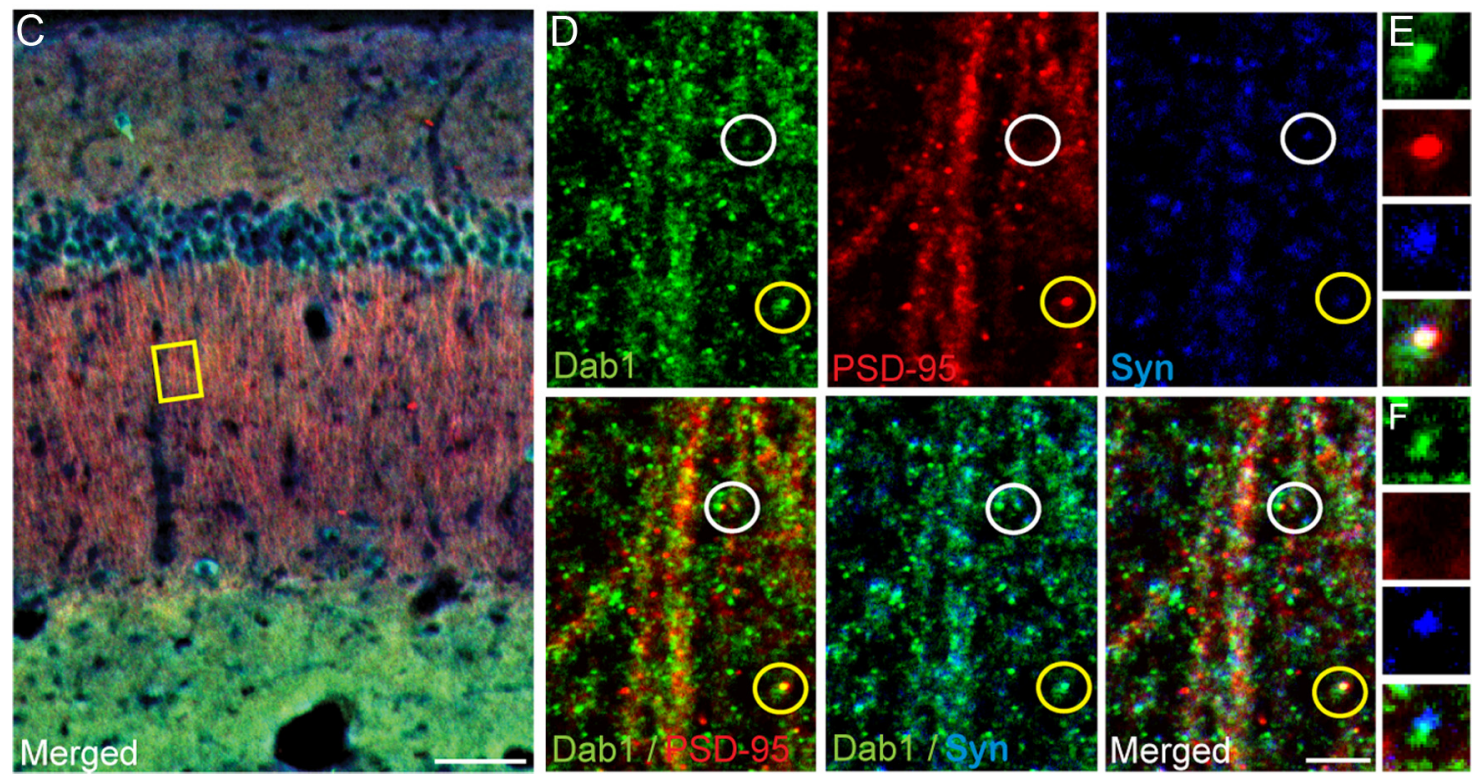

Figure 2. Synaptic localization of Dab1 in the adult forebrain. A, Western blot analysis of Dab1 in the homogenate (Hom) and crude SNS fractions of the WT and Dab1 K0 cerebral cortex and hippocampus. The data (quantified from $n=4$ WT mice) indicate that Dab1 is present at similar levels in homogenate and SNS fractions obtained from both the cortex and the hippocampus ( $p>$ 0.05). The blot was reprobed with antibodies against the postsynaptic NMDAR subunit NR1, presynaptic synapsin lla, and actin as a loading control. $\boldsymbol{B}$, Western blot analysis of Reelin and Dab1 in purified synaptic fractions. Reelin and Dab1 were present in crude SNSs (P2), synaptic membranes (LP1), and, to a lesser extent, in SV and PSD fractions. The blot was reprobed with PSD-95 and synaptophysin antibodies to confirm the purity of the fractions. C, D. Triple immunofluorescence labeling of the adult hippocampus with antibodies against Dab1 (green), PSD-95 (red), and synaptophysin (blue). The inset yellow box in Cis further magnified in $\boldsymbol{D}$ to show dendrites projecting through the stratum radiatum of the hippocampal area CA1. A triple-labeled, putative excitatory synapse is circled in yellow and magnified in $\boldsymbol{E}$, whereas a Dab1- and synaptophysin-positive (but PSD-95 negative) punctum (white circle) is magnified in $\boldsymbol{F}$. Scale bars: $\boldsymbol{C}, 50 \mu \mathrm{m} ; \boldsymbol{D}, 5 \mu \mathrm{m}$.

starting at approximately P19 (Tsien et al., 1996; Dragatsis and Zeitlin, 2000). Cre-positive, homozygous mutant mice Dab1 flox/flox (here referred to as $\mathrm{CKO}$ ) were born at a normal ratio, were fertile, and appeared healthy and indistinguishable from Cre-negative control littermates (here referred to as WT).

To confirm the specificity of Cre expression, we introduced the ROSA26-tdTomato reporter gene into the genetic background of Dab1 cKO mice. The Dab1 ${ }^{\text {flox/flox }}$ progeny that was Cre + and tdTomato + displayed an intense red fluorescence signal that was predominantly localized to forebrain structures, including the cerebral cortex and hippocampus, at 1 month (data not shown) and 2 months of age (Fig. 3A). The reporter gene was expressed throughout the neocortex at these ages. However, in the hippocampus it was mostly restricted to area CA1 and to the dentate gyrus, and excluded from area CA3 (Fig. 3A). These findings are consistent with previous reports (Tsien et al., 1996), and confirm that the CaMKII $\alpha$-Cre driver line induces genetic recombination in the expected brain regions of $\mathrm{cKO}$ mice at adult ages.

To verify the loss of Dab1 protein expression in conditional mutant mice, we dissected the cerebral cortex, hippocampus, and cerebellum from adult cKO and WT mice, and performed Western blot analysis. As expected, Dab1 levels were significantly reduced in the cerebral cortex (33.4 $\pm 7.7 \%$ of WT) and hippocampus $(48.1 \pm 6.7 \%$ of WT) of 2 -month-old cKO mice $(p<0.001$, Student's $t$ test), but not in the cerebellum (Fig. $3 B$ ). Similar results were obtained using 6-month-old mice (data not shown). We also performed immunostaining of brain sections obtained from 2- to 3-month-old WT and cKO mice using the Dab1 B3 antibody. Consistent with data shown in Figure 1, Dab1 was detected throughout the neocortex and in all subfields of the hippocampus in WT mice (Fig. 3C). However, in the cKO forebrain, Dab1 expression appeared dramatically reduced, with residual expression being restricted to a subpopulation of cells mostly located in deep cortical layers and in hippocampal area CA3 (Fig. 3C). To further examine the cell specificity of Dab1 loss, we conducted double immunofluorescence experiments using the GABAergic interneuron marker glutamic acid decarboxylase 67 (GAD67; Fig. 3D-G). In the WT hippocampus (Fig. $3 D, E$ ), Dab1 labeled mostly GAD67-negative cell bodies (presumed excitatory neurons); however, colabeling was also observed in some interneurons located mainly in s.o. and s.l.m. 


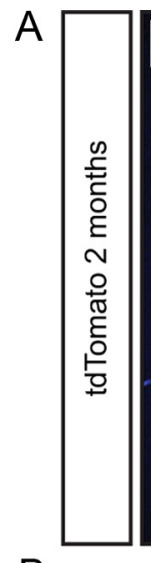

B

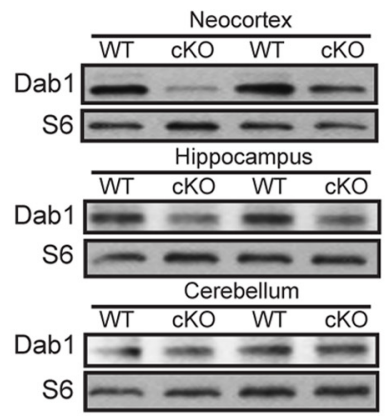

C

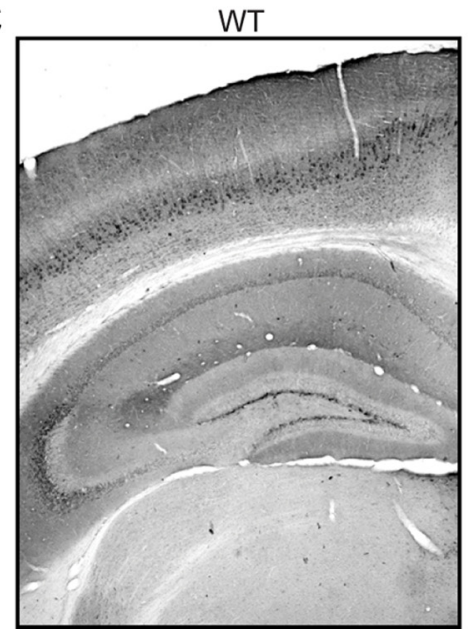

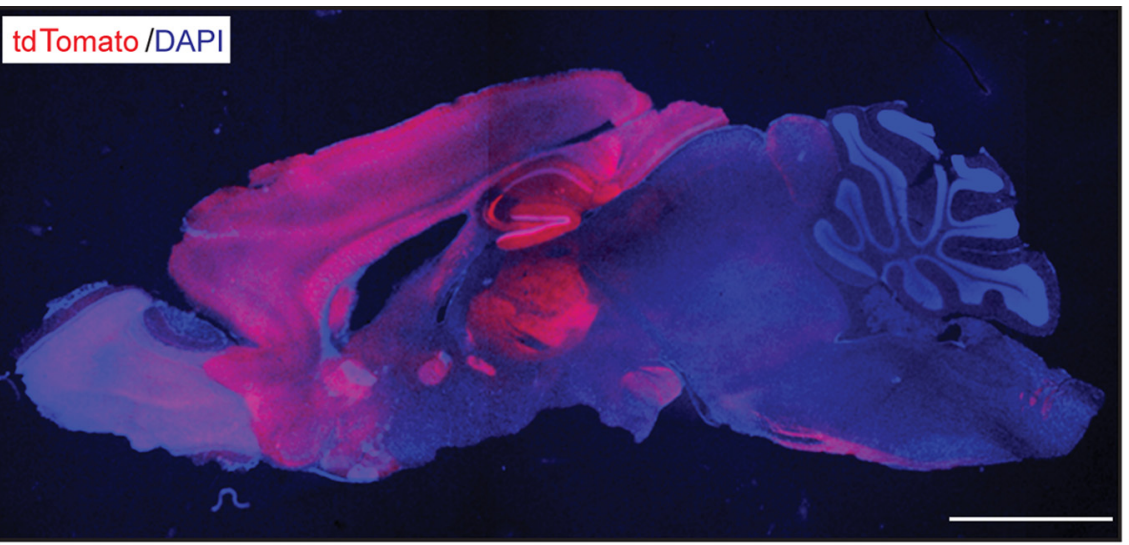

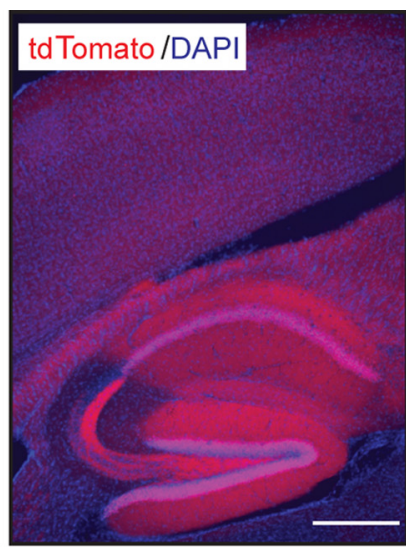

$\mathrm{Dab} 1$

Gad67
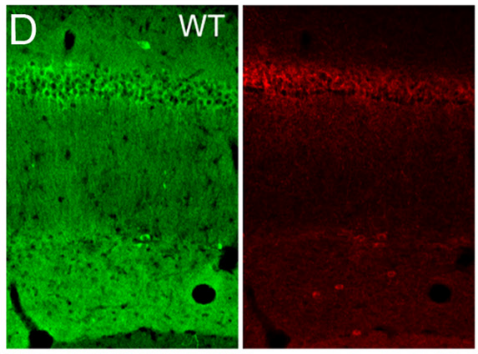

Merged (+DAPI)
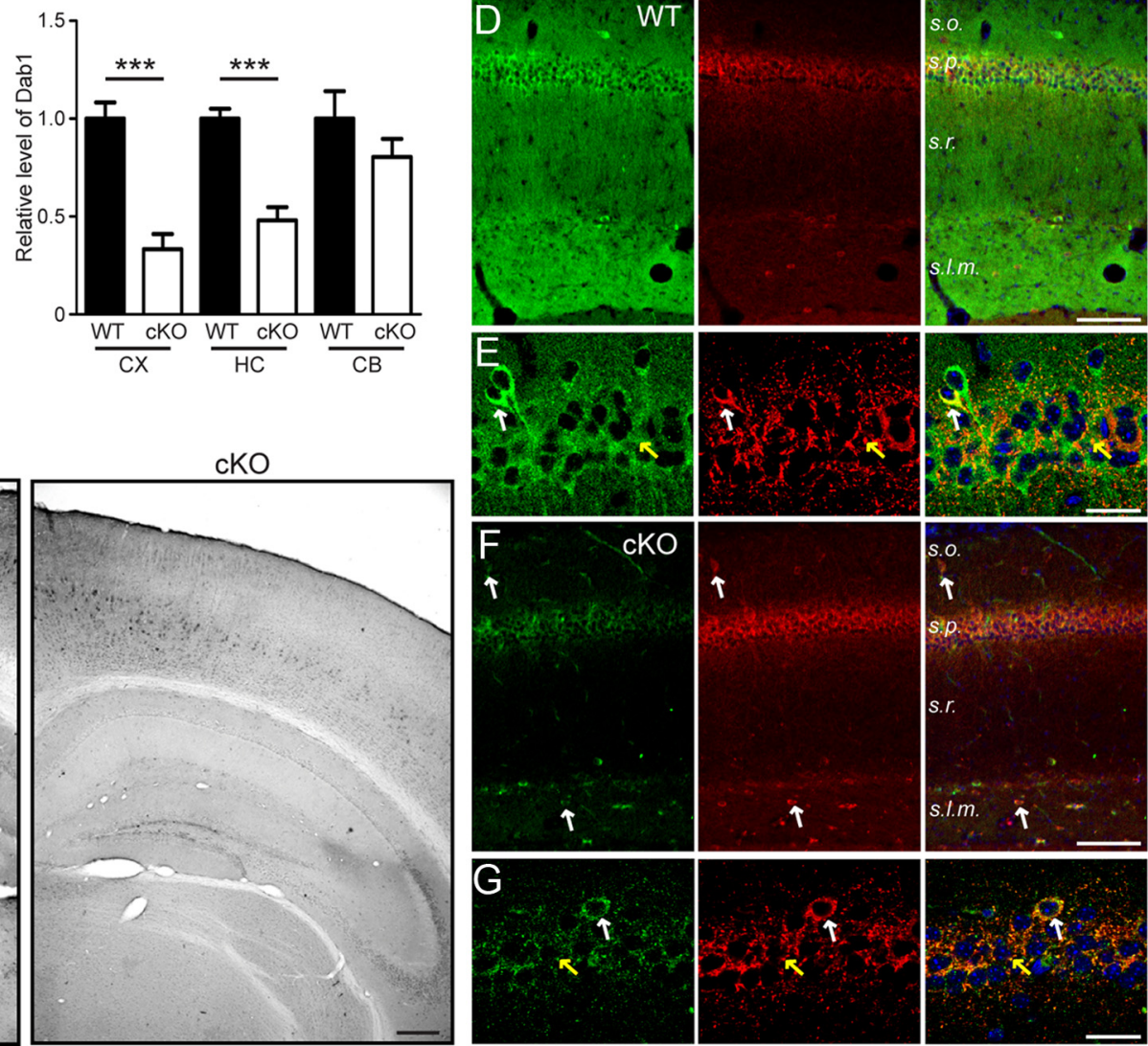

Figure 3. Adult forebrain excitatory neuron-specific loss of Dab1 expression in cK0 mice. $A$, A representative brain section obtained from a 2-month-old cK0 mouse also expressing the tdTomato reporter gene. The low-magnification example on the left shows predominant reporter gene expression in the forebrain, whereas the higher magnification example on the right shows elevated activity in the cerebral cortex, hippocampal area CA1, and dentate gyrus. Scale bars: left, $2 \mathrm{~mm}$; right, $200 \mu \mathrm{m}$. B, Western blot analysis of Dab1 in brain regions of 2-month-old WT and Dab1 cK0 mice. Blots were reprobed with antibodies against ribosomal protein $\$ 6$ as a loading control. The data were quantified from $n=4-5$ mice/genotype. Dab1 levels were significantly reduced in the cortex (CX) and hippocampus (HC), but not in the cerebellum (CB), of cK0 mice compared with WT mice. Bar graphs indicate the mean \pm SEM; ${ }^{* * *} p<0.001$. C, Immunoperoxidase staining of Dab1 in 2-month-old WT and cKO brains revealed widespread loss of Dab1 expression throughout the cortex and hippocampus. Scale bar, $200 \mu \mathrm{m}$. $\boldsymbol{D}, \boldsymbol{E}$, Double immunofluorescence of adult WT hippocampal sections stained with Dab1 (green) and GAD67 (red) antibodies. Magnified examples in $\boldsymbol{E}$ show that Dab1 is expressed mostly in the cell bodies of excitatory neurons, which are surrounded by inhibitory terminals (yellow arrows). Occasionally, colabeling of interneuron cell bodies was noted (white arrows). $\boldsymbol{F}, \boldsymbol{G}$, Double immunofluorescence of similar cK0 sections reveals the specific loss of Dab1 in excitatory, pyramidal neurons, which unmasks the residual expression of Dab1 in the interneuron cell bodies (white arrows) and terminals (yellow arrows). Scale bars, $\boldsymbol{D}$, $F, 50 \mu \mathrm{m} ; E, G, 25 \mu \mathrm{m}$.

Upon closer magnification (Fig. 3E), Dab1 and GAD67 were found to colabel the soma of GABAergic interneurons positioned in s.o. (white arrow), as well as putative perisomatic inhibitory synapses in the stratum pyramidale (s.p.; yellow arrow). This expression pattern was even more obvious in sections derived from cKO mice. Here, Dab1 was readily observed in the soma of GAD67-positive interneurons located in s.o. and s.l.m. (Fig.
$3 F, G$, white arrows), and in perisomatic inhibitory synapses in s.p. (Fig. $3 G$, yellow arrow). These data demonstrate that, in addition to excitatory neurons, Dab1 is also expressed by GABAergic basket cells, which are responsible for perisomatic inhibition of pyramidal neurons in hippocampal area CA1 (Karson et al., 2009). A large population of immature granule cells residing at the interface of the hilar region and granule cell layer was also 
found to express Dab1 in cKO sections (data not shown). Together, our data indicate that Dab1 loss in cKO mice is restricted to excitatory neurons of the adult forebrain, consistent with previous findings that the CaMKII $\alpha$ promoter is selectively activated in most excitatory neurons of the adult forebrain (Tsien et al., 1996; Sík et al., 1998; Dragatsis and Zeitlin, 2000).

\section{Analysis of brain anatomy and excitatory synaptic structure in Dab1 cKO mice}

To examine the consequence of Dab1 loss in excitatory neurons of the adult forebrain, we stained brain sections of 2-month-old $\mathrm{cKO}$ and WT control mice with thionin. All cortical brain regions appeared normal at low magnification (Fig. 4A), and cellular layers of the neocortex and hippocampus appeared intact (Fig. $4 B)$. Contrary to previous findings resulting from the injection of Reelin-interfering antibodies in the adult dentate gyrus (Heinrich et al., 2006), no granule cell dispersion was observed in adult cKO mice. Similarly, no neuroanatomical defects were observed in $\mathrm{CKO}$ mice at older ages (6-11 months, data not shown). These findings are consistent with the established role of Reelin-Dab1 signaling in the development of cellular layers, since this process is largely complete before the time of onset of Cre expression in cKO mice $(\sim 1$ month of age). Furthermore, they demonstrate that Reelin-Dab1 signaling is not required to maintain the integrity of cellular layers in the adult forebrain.

To determine whether neuronal orientation, dendrite arborization, and spine formation are affected in Dab1 cKO mice, we performed Golgi staining of 2-month-old cKO and WT brains. The gross morphology of excitatory hippocampal pyramidal neurons in area CA1 (Fig. 4C,D) as well as cortical neurons (data not shown), which exhibit almost complete loss of Dab1 in cKO mice by this age, appeared normal. To further analyze the branching pattern of apical dendrites in hippocampal area CA1, we traced primary and secondary branches of individual pyramidal neurons in the s.r., and measured the cumulative number of secondary branches at increasing distances from the soma. These data indicate that the branching pattern of $\mathrm{cKO}$ neurons is similar to that of WT neurons ( $p>0.05$; Fig. $4 D$ ). We also analyzed soma and primary apical dendrite orientation of traced WT and cKO pyramidal neurons, as previously described (O'Dell et al., 2012). The orientation of both the soma and apical dendrite was found to be unaffected by the loss of Dab1 in cKO neurons $(p>0.05$; Fig. $4 D$ ). These findings demonstrate that Reelin-Dab1 signaling is not required to maintain the morphology or the orientation of dendritic trees in the adult forebrain. Next, we collected highmagnification images of Golgi-stained secondary apical dendrites of pyramidal neurons in area CA1 to visualize spines (Fig. 4C). Mature spines with a mushroom-like head were readily observed in both genotypes, and represented the great majority of imaged spines. Therefore, we did not attempt to classify them into subcategories, but measured their density and head size. Our analysis reveals that dendritic spine density was not altered in Dab1 cKO mice (Fig. $4 E ; p>0.05$, Student's $t$ test). However, the crosssectional area was significantly smaller in $\mathrm{CKO}$ mice (Fig. $4 F ; p<$ 0.0003 , Student's $t$ test). The spine area measurements were $0.39 \pm 0.0173 \mu \mathrm{m}^{2}$ in WT and $0.30 \pm 0.0153 \mu \mathrm{m}^{2}$ in Dab1 cKO mice ( $n=50$ neurons per genotype). Based on previous reports that the geometry of dendritic spines is a key determinant of their glutamate sensitivity (Matsuzaki et al., 2001, 2004; Hayashi and Majewska, 2005), these findings suggest that loss of Dab1 might affect glutamatergic synaptic transmission and synaptic plasticity in adult $\mathrm{cKO}$ mice.
We have previously reported that Reelin haploinsufficiency during development results in alterations of the biochemical and physiological properties of adult hippocampal excitatory synapses (Qiu and Weeber, 2007; Ventruti et al., 2011). To address whether Reelin signaling loss in the adult forebrain disrupts the molecular composition of synapses, we prepared protein homogenate and crude SNS fractions from WT and Dab1 cKO mice at 2 months of age, and analyzed them by Western blotting (Fig. 4G). As expected, the levels of Dab1 were significantly decreased in homogenate and SNS fractions derived from cKO mice (50.2 \pm $9.6 \%$ of WT in homogenate, $48.8 \pm 7.8 \%$ of WT in SNS). However, we found no significant changes in the levels of postsynaptic protein markers such as PSD-95, NR2A, NR2B, and NR1 (Fig. $4 G$; PSD-95, $89.5 \pm 2.3 \%$ of WT in homogenate, $92.4 \pm 4.2 \%$ of WT in SNS; NR2A, $110.4 \pm 10.1 \%$ of WT in homogenate, $96.1 \pm$ $4.1 \%$ of WT in SNS; NR2B, $99.4 \pm 4.8 \%$ of WT in homogenate, $92.7 \pm 5.4 \%$ of WT in SNS; NR1, $113.4 \pm 12.2 \%$ of WT in homogenate, $96.9 \pm 7.8 \%$ of WT in SNS). The levels of presynaptic protein markers such as synapsin IIa and synaptophysin were similar in homogenate fractions, but they were marginally decreased in the SNS fractions of cKO mice (synapsin IIa, $104.3 \pm$ $4.0 \%$ of WT in homogenate, $86.0 \pm 2.4 \%$ of WT in SNS, $p=$ 0.071 in SNS; Synaptophysin, $98.6 \pm 3.7 \%$ of WT in homogenate, $87.0 \pm 1.5 \%$ of WT in SNS, $p=0.054$ in SNS) (Fig. $4 G$; data not shown). Together, these results indicate that Dab1 is not required for dendritic spine formation, maintenance, or composition in the adult hippocampus, but plays a role in maintaining normal spine size.

\section{Basal Akt and ERK1/2 signaling abnormalities in the adult Dab1 cKO forebrain}

Given the spine anomalies we observed in Dab1 cKO mice, we next sought to elucidate potential molecular underpinnings of these changes. A multitude of intracellular signaling pathways have been implicated in regulating dendritic spine formation and maturation, including the $\mathrm{PI} 3 \mathrm{~K}$ and downstream protein kinase B (PKB/Akt; Cuesto et al., 2011; Majumdar et al., 2011), as well as mitogen-activated protein kinases, including ERK1 and ERK2 (Goldin and Segal, 2003; El Gaamouch et al., 2012). To determine whether loss of Dabl in the adult forebrain affects these intracellular signaling pathways, we performed Western blot analysis of WT and cKO cortical and hippocampal lysates. At a young adult age (2 months), we detected no differences in the levels of activated, phosphorylated Akt (Ser473; p-Akt) and activated, phosphorylated ERK1 and ERK2 (Thr202/Tyr204; p-ERK1/2) (Fig. $5 A$ ). Intriguingly, however, we found a significant reduction in the basal levels of p-Akt and p-ERK1/2 in both the cortex and hippocampus of mature adult (4-month-old) Dab1 cKO mice compared with WT littermates (Fig. 5B). Specifically, the levels of p-Akt were $55.7 \pm 5.3 \%$ of WT in the cortex $(p<0.01$, onesample $t$ test), and $54.0 \pm 3.1 \%$ of WT in the hippocampus of Dab1 cKO mice ( $p<0.001$, one-sample $t$ test). Similarly, the levels of p-ERK2 were $57.3 \pm 9.7 \%$ of WT in the cortex, and $69.1 \pm 7.7 \%$ of WT in the hippocampus of the Dab1 cKO mice ( $p<0.05$ for both, one-sample $t$ test). In support of these findings, the phosphorylation of downstream Akt substrates, including mTOR (Ser2448) and GSK3 $\beta$ (Ser9), was also markedly reduced in the forebrain of 4-month-old Dab1 cKO mice (data not shown), whereas the levels of total kinase were not affected. These results demonstrate that chronic loss of Dab1 in excitatory neurons leads to deficits in the basal activity of PI3K/Akt and ERK1/2 signaling pathways in the mature adult forebrain. 
A
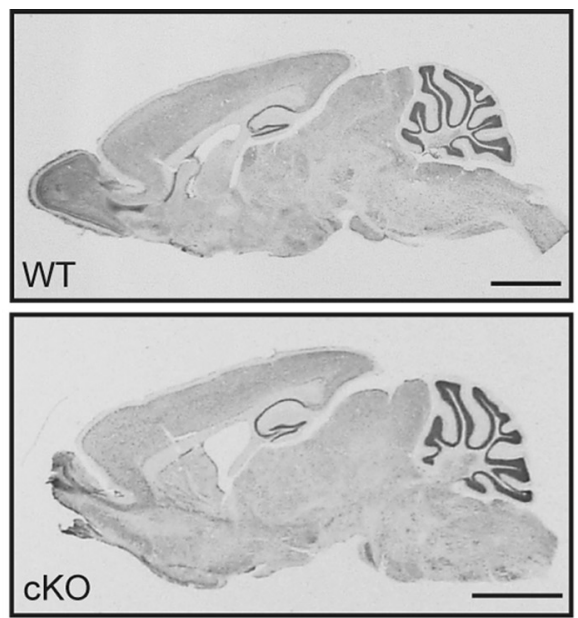

B

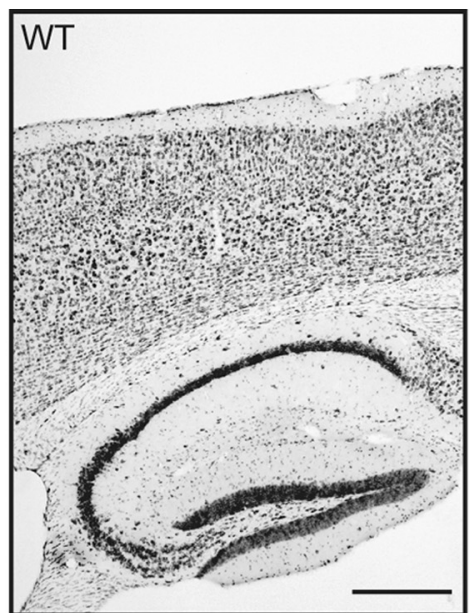

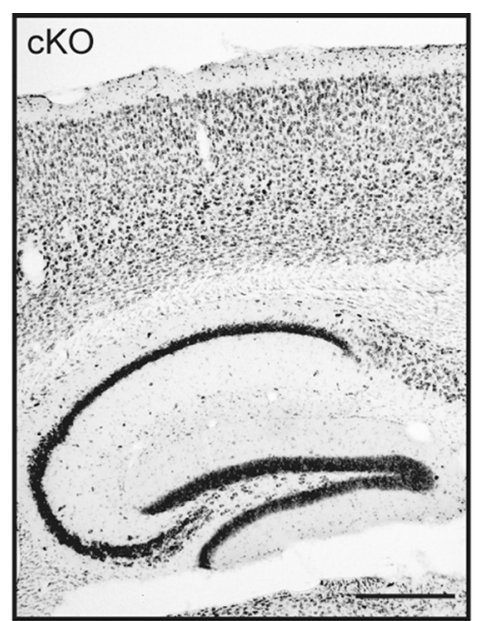

C
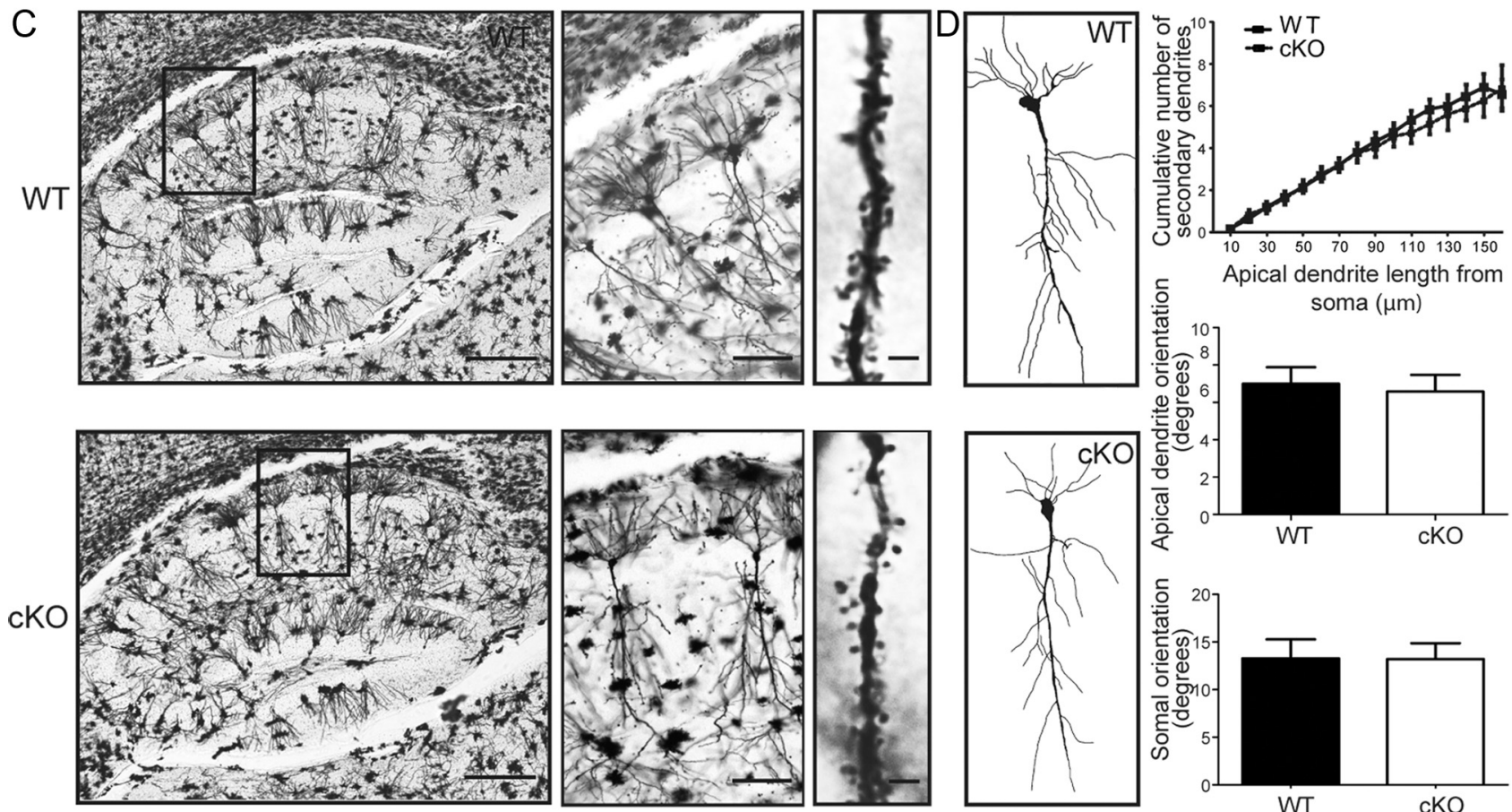

E

Spine Density
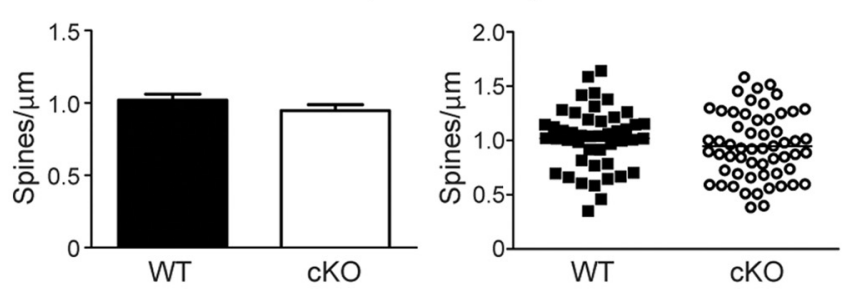

F

Spine Area
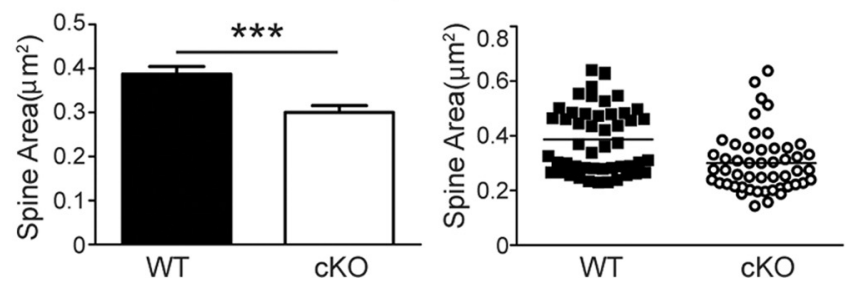

G
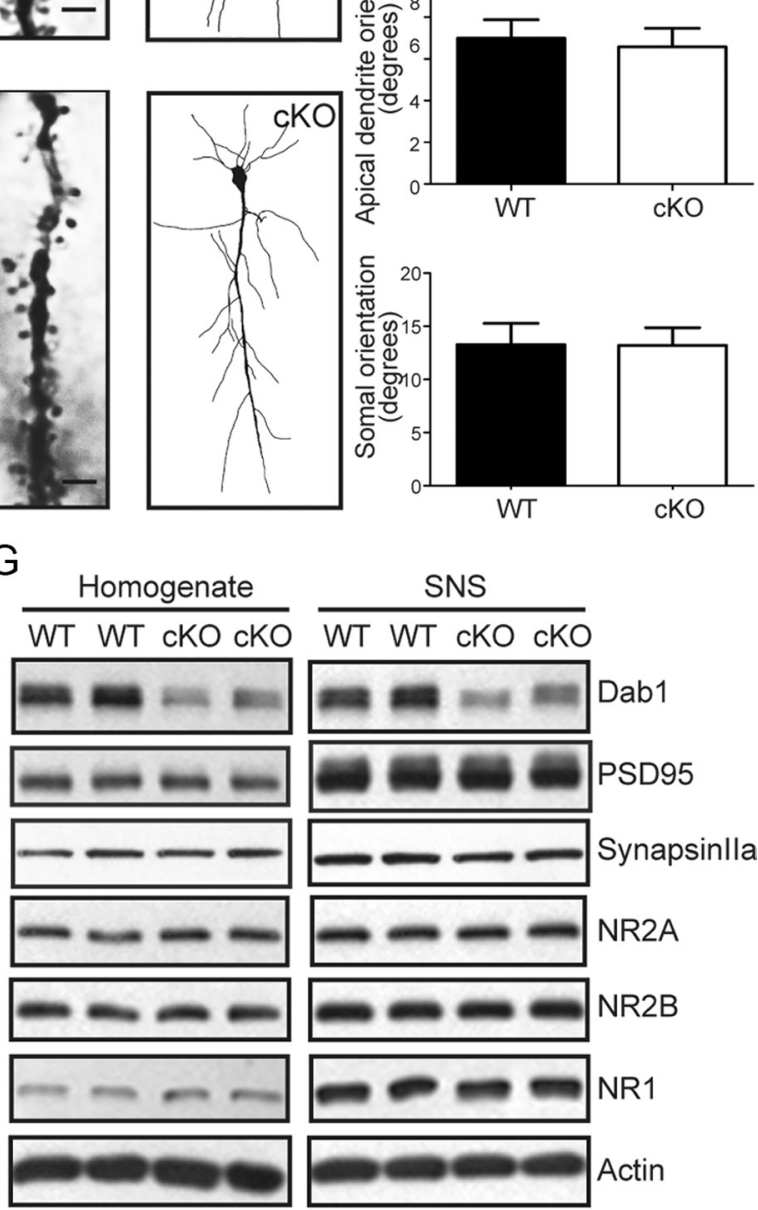

WT

SNS
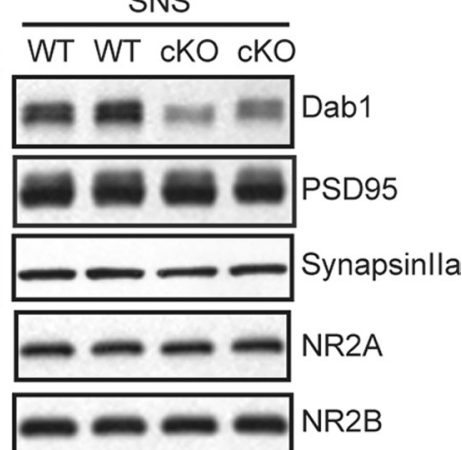

Figure 4. Anatomy, dendrite morphology, and spine analysis in the Dab1 cKO hippocampus. $\boldsymbol{A}, \boldsymbol{B}$, Sagittal sections of 2-month-old WT and Dab1 cK0 mice were stained with thionin. All main regions appear normal in whole brain images $(\boldsymbol{A})$. Magnified images of the cortex and hippocampus also show no obvious defects in cellular layers (B). Scale bars: (Figure legend continues.) 
A 2 months
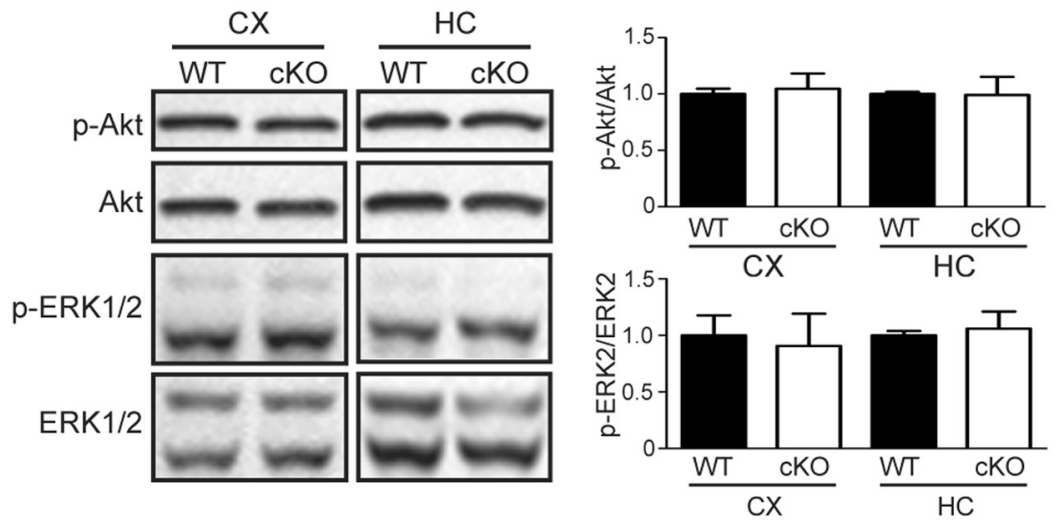

B 4 months

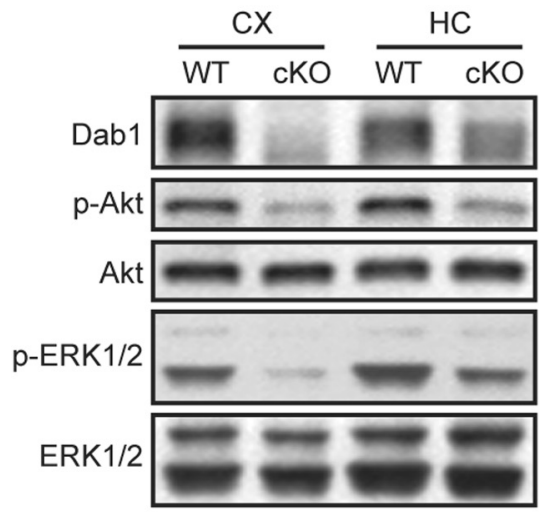

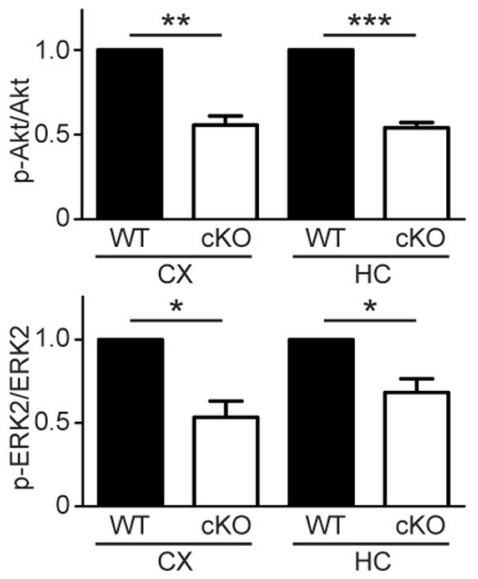

Figure 5. Basal Akt and ERK1/2 signaling in adult Dab1 cK0 mice. Western blot analysis of the phosphorylation status of Akt and ERK1/2 in adult WT and Dab1 cKO cortex (CX) and hippocampus (HC). The data were quantified as the ratio of phospho-Akt (p-Akt) over total Akt, and phospho-ERK2 (p-ERK2) over total ERK2. There were no significant differences in the levels of $p$-Akt and $\mathrm{p}$-ERK1/2 between genotypes at 2 months of age $(\boldsymbol{A})$. However, at 4 months of age $(\boldsymbol{B})$ the levels of $p$-Akt and $\mathrm{p}$-ERK2 were significantly reduced in both the cortex and hippocampus of Dab1 cK0 compared with WT mice ( $n=4$ mice per genotype). Bar graphs indicate the mean $\pm \mathrm{SEM},{ }^{*} p<0.05,{ }^{* *} p<0.01,{ }^{* * *} p<0.001$.

\section{Activity-dependent ERK1/2 signaling in Dab1 mutant cultures}

Since spine abnormalities were present in cKO mice at 2 months of age, before the appearance of detectable deficits in basal signaling, we wondered whether altered kinetics or reduced levels of

\footnotetext{
$\leftarrow$

(Figure legend continued.) $\quad A, 2 \mathrm{~mm} ; \boldsymbol{B}, 200 \mu \mathrm{m}$. C, Images of Golgi-stained hippocampus from 2-month-old WT and cKO mice. Insets on the left were further magnified to show individual pyramidal neurons and their dendrites in area CA1 (middle). Representative $z$-stack images of secondary apical dendrites bearing spines are also shown (right). Scale bars: left, $300 \mu \mathrm{m}$; middle, $100 \mu \mathrm{m}$; right, $2 \mu \mathrm{m}$. D, Tracing and analysis of dendrite branching and neuronal orientation. Examples of traced WT and cKO pyramidal neurons in area CA1 are shown. Twentysix WT and 17 cK0 neurons from 4 to 5 mice per genotype were used for branching analysis; 40 WT and 34 cK0 neurons from 4 to 5 mice per genotype were used for neuronal orientation analysis. No significant change in secondary dendrite branching or orientation of apical dendrites and cell body is apparent. $\boldsymbol{E}, \boldsymbol{F}$, Quantification of spine density $(\boldsymbol{E})$ and area $(\boldsymbol{F})$. There was no significant difference in spine density between WT and $c K 0$ neurons. However, spine area was significantly smaller in Dab1 cK0 compared with WT mice $\left(^{* * *} p<0.0001\right)$. G, Western blot analysis of Dab1 and synaptic protein markers in the homogenate and crude SNS fractions of WT and Dab1 KO hippocampus. The blots were probed sequentially or in parallel with antibodies against Dab1, postsynaptic PSD-95, NMDAR subunits NR1 and NR2A, and presynaptic synapsin Ila. Actin was used as a loading control. Although Dab1 levels were decreased in samples obtained from cKO mice, the levels of all analyzed synaptic proteins appear similar between genotypes (data from 5 to 6 mice per genotype).
}

ERK1/2 signaling in response to neuronal activity could underlie structural spine defects. Intracellular signaling is critical for conveying information from the site of postsynaptic activation to the nucleus, which in turn enables chromatin remodeling and changes in gene expression that permit long-term synaptic plasticity (Wiegert and Bading, 2011). In particular, the activation of ERK1/2 is necessary for the expression and maintenance of LTP (Tsokas et al., 2007; Gobert et al., 2008; Maharana et al., 2013). To determine whether Dab1 is required for activitydependent stimulation of ERK1/2 signaling, we analyzed activity-dependent ERK1/2 signaling in adult hippocampal slices ex vivo. Transverse hippocampal slices were prepared from WT and Dab1 cKO mice at 2 months of age, a time point when differences in basal ERK1/2 activation were not yet evident (Fig. 5). The slices were allowed to recover for $2 \mathrm{~h}$, and then were stimulated for 10 min with 25 $\mathrm{mM}$ of the potassium channel blocker TEA-Cl to induce robust cLTP in hippocampal area CA1, as described previously (Hanse and Gustafsson, 1994). Hippocampal area CA1 was dissected for protein isolation from nontreated slices and from slices that received TEA-Cl at 5 and $45 \mathrm{~min}$ following treatment. At $5 \mathrm{~min}$ post-TEA-Cl treatment, a rapid and robust stimulation of ERK1 phosphorylation (p-ERK1/2 Thr202/Tyr204) was observed in WT $(395 \pm 46.2 \%$; $p<0.05$, unpaired $t$ test) and Dab1 cKO slices $(336 \pm 42.7 \%$; $p<0.05$, unpaired $t$ test; Fig. $6 A$ ). Although the relative changes in the ratio of p-ERK1/ERK in Dab1 cKO were slightly lower than in WT slices, comparison between these groups did not reach statistical significance. The levels of p-ERK1 returned to baseline similarly in both WT $(103 \pm 11.4 \%)$ and Dab1 cKO $(81.9 \pm 6.70 \%)$ slices at 45 min post-TEA-Cl treatment (Fig. 6B; quantification not shown). On the other hand, significant differences were observed in the dynamics of ERK2 phosphorylation in WT and Dab1 cKO slices following cLTP induction. At $5 \mathrm{~min}$ following TEA-Cl treatment, WT slices exhibited a $234 \pm 13.1 \%$ increase in relative p-ERK2 levels $(p<$ 0.001 , unpaired $t$ test) versus a $187 \pm 10.2 \%$ increase in Dab1 cKO slices $(p<0.05$, unpaired $t$ test). The magnitude of ERK2 activation was significantly reduced in the Dab1 cKO compared with WT slices $(p<0.01$, two-way ANOVA with Bonferonni's post hoc test; Fig. $6 A$ ). At 45 min following treatment (Fig. 6B), WT slices still showed a $126 \pm 5.2 \%$ increase in relative p-ERK2 levels ( $p<0.05$, unpaired $t$ test), whereas Dab1 cKO slices returned to baseline levels ( $97.8 \pm 3.0 \% ; p>0.05$, unpaired $t$ test). Thus, the sustained activation of ERK2 at $45 \mathrm{~min}$ after cLTP induction was blunted in Dab1 cKO compared with WT slices ( $p<0.05$, two-way ANOVA with Bonferroni's post hoc test). These data suggest that Dab1 serves a critical function in regulating the kinetics of activity-dependent MAPK activation in the 
adult brain, as its deficiency hinders the sustained activation of ERK2 following synaptic potentiation.

\section{Physiological abnormalities in Dab1 cKO hippocampal slices}

Application of Reelin to hippocampal slices enhances LTP at Schaffer collateral synapses through binding both ApoER2 and VLDLR, and promoting activation of NMDARs (Weeber et al., 2002; Beffert et al., 2005). We have thus far presented evidence of biochemical and structural changes in Dab1 cKO, which is the first conclusive evidence that Dab1 continues to regulate synaptic function in the adult brain. In line with previous studies, we hypothesized that impaired activitydependent kinase regulation and the inability to convey Reelin signaling may culminate in perturbed synaptic plasticity in Dab1 cKO mice. To test this hypothesis, we used acute hippocampal slices obtained from adult WT and Dab1 cKO mice (3-6 months old) to examine synaptic transmission, short-term plasticity, long-term plasticity, and Reelin responsiveness at the well defined Schaffer collateral synapses.

We first evaluated overall synaptic transmission by comparing the amplitude of the evoked fiber volley to the slope of the fEPSP at increasing stimulus intensities (Fig. 7A). Comparison of the linear-fitted plot revealed no differences between WT (slope $=2.176 \pm 0.26)$ and Dab1 cKO slices (slope $=1.929 \pm 0.316$ ), suggesting that overall synaptic transmission was normal. Short-term synaptic plasticity was evaluated by the amount of PPF with interpulse intervals (IPIs) ranging from 20 to $300 \mathrm{~ms}$ (Fig. $7 B$ ). Significant reductions in PPF were found at the $40 \mathrm{~ms}$ interval ( $148 \pm 7.02 \% \mathrm{WT}, 134 \pm$ $3.16 \%$ cKO; $p<0.05$, unpaired $t$ test), but not at other intervals.

We have previously reported deficits in LTP induced by either two trains of $100 \mathrm{~Hz}$ stimulation (HFS) or theta-burst stimulation (TBS-LTP) in ApoER2 KO mice (Weeber et al., 2002). TBSLTP consists of five trains of four pulse bursts at $200 \mathrm{~Hz}$, repeated six times with an interburst interval of $10 \mathrm{~s}$. Using this protocol, we found a significant reduction in LTP induction (i.e., first 10 min averaged) in the Dab1 cKO $(130 \pm 7.19 \%)$ compared with WT controls ( $164 \pm 8.81 \%$; $p<0.05$, unpaired $t$ test; Fig. $7 C)$. Moreover, the maintenance of LTP (i.e., final 10 min averaged) in the Dab1 cKO (124 $\pm 10.3 \%)$ was significantly reduced compared with WT controls (152 $\pm 6.9 \%$; $p<0.05$, unpaired $t$ test; Fig. $7 C$ ). Using HFS, we found reduced LTP in the Dab $1 \mathrm{cKO}$ $(115 \pm 10.8 \%)$ compared with WT slices $(156 \pm 111.5 \%$; $p<$ 0.05 , unpaired $t$ test) when the final 20 min of recording were averaged (Fig. 7D). Although the induction of LTP (first 10 $\mathrm{min})$ appeared to be reduced in the $\mathrm{CKO}(118 \pm 14.6 \%)$ compared with WT $(154 \pm 17.3)$, this effect was not statistically significant $(p=0.176)$.

Previous work by our group and others has established that Reelin potently enhances TBS-LTP in a manner that depends on two critical domains of ApoER2: the NPxY motif, which binds
Dab1 (Beffert et al., 2006), and the alternatively spliced exon19 (Beffert et al., 2005), which binds PSD-95 and JIP1/2. To determine whether Dab1 is required for the enhancement of LTP by Reelin, we treated WT and Dab1 cKO slices with mock or Reelinconditioned media $10 \mathrm{~min}$ before inducing TBS-LTP. Confirming previous studies, Reelin treatment enhanced the induction of LTP (first $10 \mathrm{~min}$ ) in WT mice (205 $\pm 10.1 \%$ with Reelin vs $153 \pm 7.17 \%$ with mock; $p<0.05$, unpaired $t$ test; Fig. $7 E)$. The enhancement of LTP by Reelin was maintained even through the final $10 \mathrm{~min}$ of recording (177 $\pm 14.8 \%$ with Reelin vs $141 \pm$ $6.83 \%$ with mock; $p<0.05$, unpaired $t$ test). Conversely, Reelinconditioned medium had no effect on TBS-LTP in Dab1 cKO when compared with mock-treated slices at any time during recording (Fig. $7 F$ ). These data demonstrate that Dab1 affects synaptic plasticity and it is absolutely required for the modulation of hippocampal LTP by Reelin.

\section{Behavioral abnormalities in adult Dab1 cKO mice}

Reelin haploinsuffiency in reeler heterozygous mice (Qiu et al., 2006b) or the loss of individual Reelin receptors ApoER2 or VLDLR (Weeber et al., 2002) leads to impairments in hippocampal-dependent associative learning. These previous studies used mouse models that have reduced, but not ablated, Reelin signaling. Homozygous reeler mutant or double receptor $\mathrm{KO}$ mice could not be used for behavioral studies because of neurodevelopmental confounds, including neuronal ectopia (Trommsdorff et al., 1999), delayed dendrite maturation (Niu et al., 2004), and impaired synaptic development (Niu et al., 2008; Ventruti et al., 2011). To determine whether Dab1 (and thus Reelin signaling) is required for cognitive function we conducted 

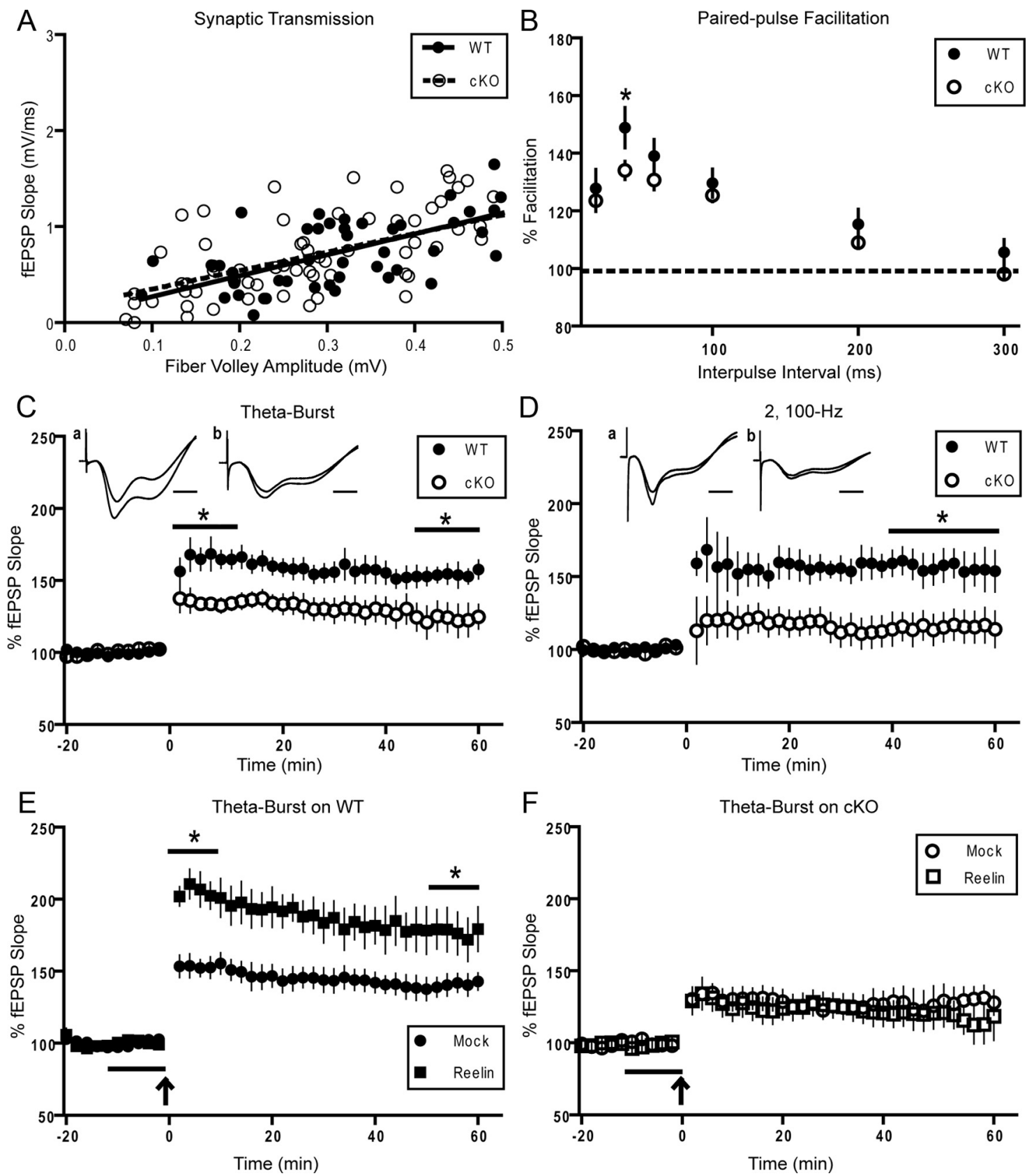

Figure 7. Altered synaptic function in adult Dab1 cK0 mice. Hippocampal slices were obtained from 3- to 6-month-old WT and Dab1 cK0 mice. $\boldsymbol{A}$, Normal synaptic transmission was observed when comparing the slope of the field EPSP versus the fiber volley amplitude at increasing intensities for WT (,$n=11$ slices, 4 mice $)$ and cKO mice $(\bigcirc, n=18$ slices, 4 mice). B, Short-term synaptic plasticity was evaluated by the amount of PPF with IPIs ranging from 20 to $300 \mathrm{~ms}$ in WT $(\mathbf{O}, 20$ slices, $n=5$ mice $)$ and cK0 mice $(\bigcirc, 34$ slices, $n=6$ mice). Significant reductions in PPF were found at the $40 \mathrm{~ms} \mathrm{IPI}\left({ }^{*} p<0.05\right)$. C, LTP was induced with TBS. The first and final $10 \mathrm{~min}$ of recording were averaged separately, revealing both a reduction in LTP induction $\left({ }^{*} p<0.05\right)$ and maintenance $\left({ }^{*} p<0.05\right)$ in Dab1 cKO $(\bullet, 15$ slices, $n=7$ mice $)$ compared with WT controls $(\mathbf{O}, 13$ slices, $n=6$ mice), respectively. Representative traces are included. Scale bar, 5 ms. D, LTP was induced by HFS consisting of two trains at $100 \mathrm{~Hz}$ in WT $(-8$ slices, $n=4$ mice $)$ and Dab1 cK0 mice $(O, 11$ slices, $n=5$ mice). A reduction of LTP in cK0 slices compared with WT was observed when the final 20 min of recording was averaged ( ${ }^{*} p<0.05$ ), but not the first $10 \mathrm{~min}$. Representative traces are included. Scale bar, $5 \mathrm{~ms}$. $\boldsymbol{E}$, Mock- and Reelin-conditioned medium was applied for 10 min before inducing LTP with TBS (indicated by gray line). Reelin treatment ( $\mathbf{\square}, 8$ slices, $n=3$ mice) was found to enhance LTP relative to mock treatment $\left(\mathbf{O}, 15\right.$ slices, $n=5$ mice) in WT mice $\left({ }^{*} p<0.05\right)$. $\boldsymbol{F}$, Reelin-conditioned medium $(\square, 9$ slices, $n=3$ mice) had no effect on TBS-induced LTP in Dab1 cK0 slices when compared with mock medium $(\bigcirc, 7$ slices, $n=3$ mice). For all data representation, except $\boldsymbol{A}$, measurements from individual slices were averaged per mouse.

a behavioral characterization of adult cKO and WT littermates at 3-6 months of age. We first performed a standard open-field test with a 30 min duration and found no differences in overall locomotor activity measured by distance traveled (Fig. $8 \mathrm{~A}$ ) or percentage time spent in the center of the open field, a measure of thigmotactic behavior or anxiety (Fig. $8 B$ ). A battery of other behavioral tests was implemented to ensure that observed deficits were not due to underlying physical or behavioral deficits. No differences were detected in measures of activity or anxiety in the elevated plus maze, motor coordination or learning in the rotarod test, or short-term memory in the y-maze test of spontaneous alternations (data not shown). To test for associative learning, we performed a two-trial fear conditioning protocol on WT and Dab1 cKO mice by pairing an aversive stimulus (mild 
A
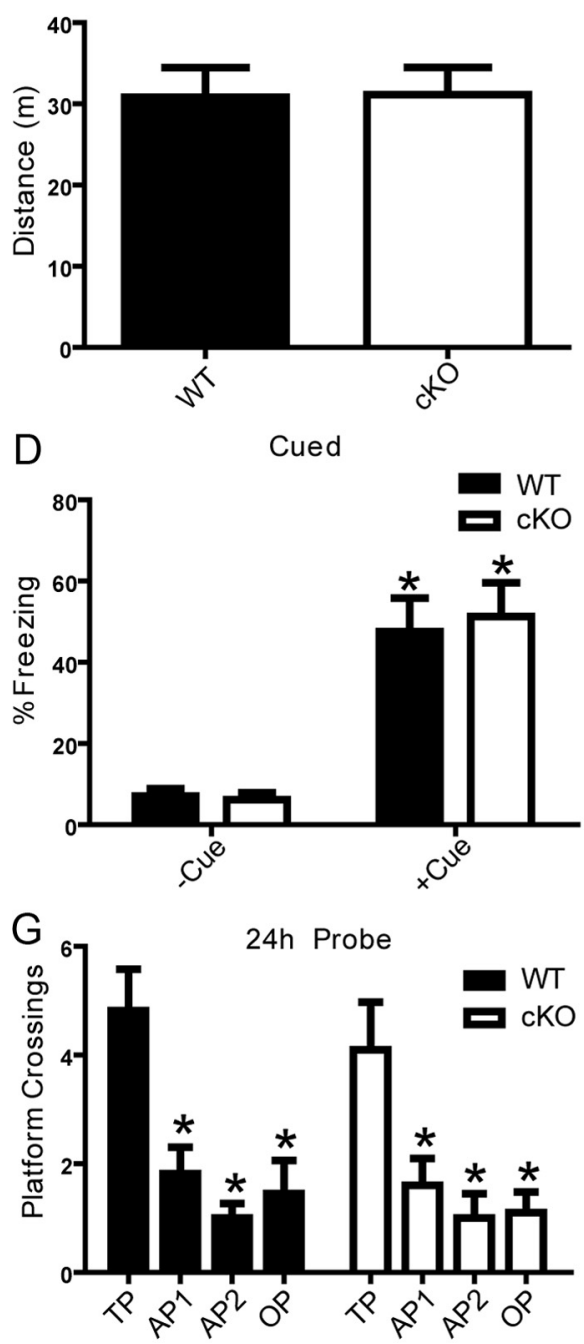

B

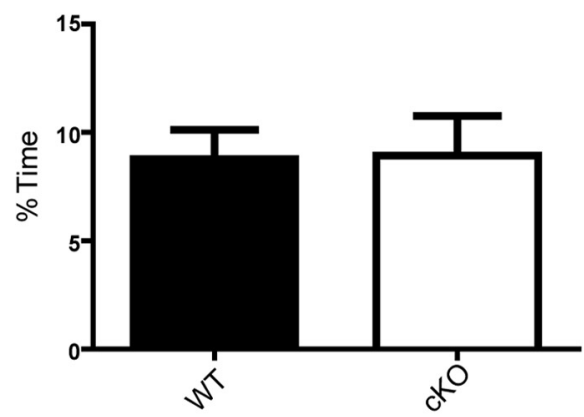

$\mathrm{E}$

Context
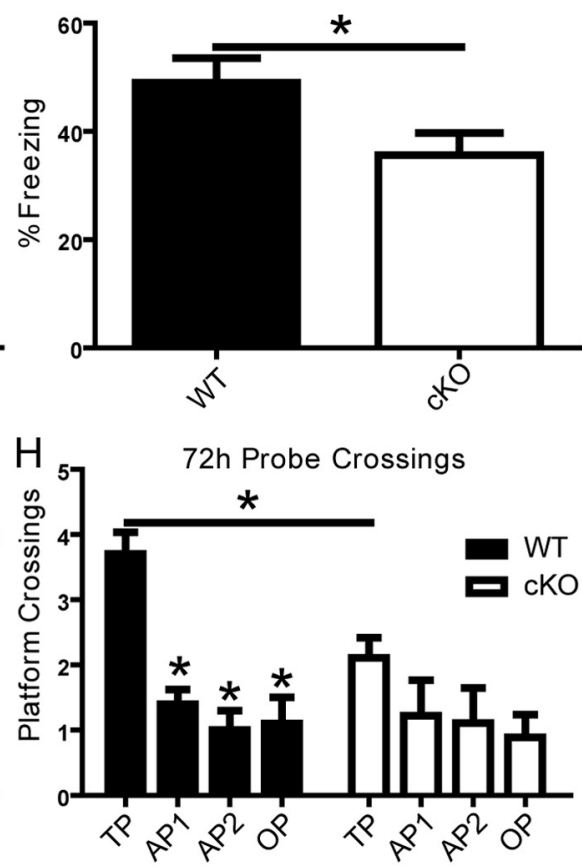

C

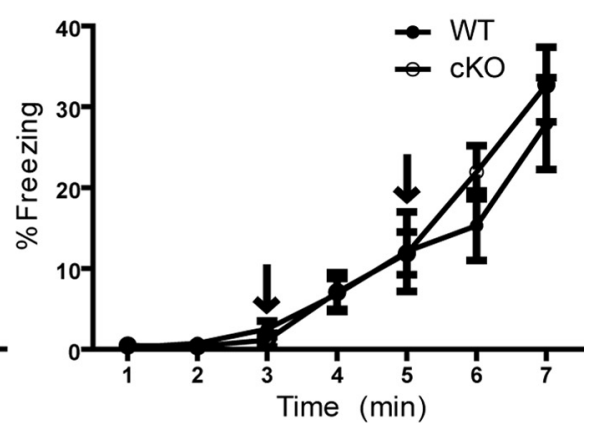

$\mathrm{F}$
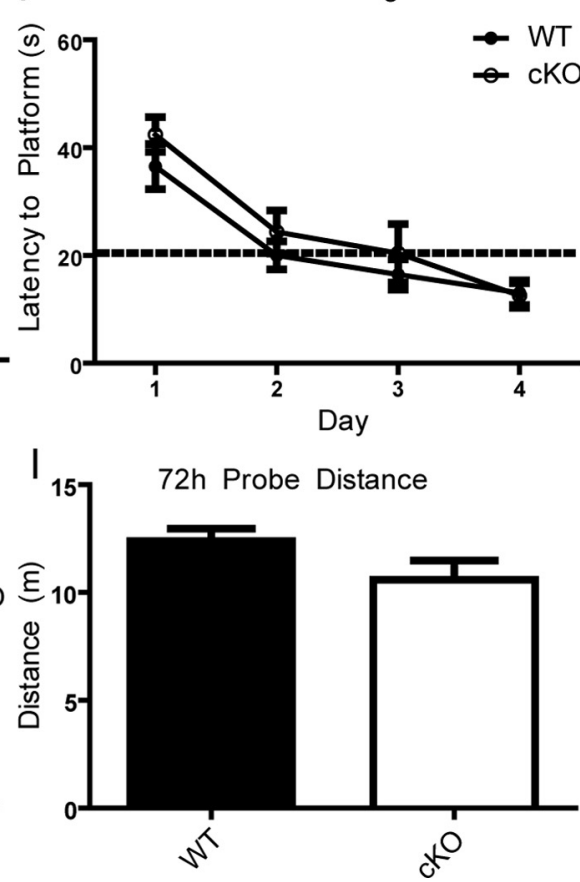

Figure 8. Normal fear associative learning requires Dab1. $A, B$, Differences in locomotor activity and anxiety were evaluated using a 30 min open-field test. The Dab1 $\mathrm{cK} 0 \mathrm{mice}(n=11)$ and WT controls $(n=11)$ exhibited similar levels of activity. Two-trial fear conditioning was used to determine associative learning at $24 \mathrm{~h}$ following two CS-US pairings. $\boldsymbol{C}, \boldsymbol{D}$, No differences were seen in freezing rates during training or in a novel context in the absence or presence of the CS (tone) when comparing WT and cKO mice. $\boldsymbol{E}$, WT mice $(n=11)$ exhibited a greater conditioning to the context compared with Dab1 cKO $\left(n=11 ;{ }^{*} p<0.05\right)$. $\boldsymbol{F}-\mathbf{I}$, Hidden-platform water maze was used to assess spatial learning and memory. No differences between WT and cK0 were seen in latency to platform across $4 \mathrm{~d}$ of training ( 4 trials/d). A $60 \mathrm{~s}$ probe trial was conducted at $24 \mathrm{~h}$ post-training. No significant difference was found in the number of target platform (TP) crossings by WT ( $n=11$ ) versus Dab1 cK0 mice $(n=10)$. Both genotypes crossed into the TP significantly more times than in other pseudo-platform areas ( $\left.{ }^{*} p<0.05\right)$. At $72 \mathrm{~h}$, a probe trial revealed that WT mice crossed into the TP significantly more times than cKO and compared with other platform regions $\left({ }^{*} p<0.05\right.$, two-way ANOVA using the Bonferroni's posthoc test). No difference was seen in distance traveled between the genotypes. OP, opposite platform; AP1, adjacent platform 1; AP2, adjacent platform 2.

footshock) with an acoustic tone (CS; white noise) in a novel context. The fear response was determined by measuring the frequency at which normal motor behavior was disrupted by freezing, a period of watchful immobility. The extent of freezing to the acoustic tone and shock during training was not significantly different between animal groups (Fig. 8C). Long-term associative memory was assessed by measuring the freezing response to the original context (context test), or to the tone in a novel context (cued test) at $24 \mathrm{~h}$ postconditioning. Our data show that Dab1 cKO mice $(35.6 \pm 4.07 \%)$ froze significantly less than WT controls $(49.0 \pm 4.55 \%)$ in the context test (Fig. $8 E ; p<0.05$ ), but not in the cued test (Fig. $8 D$ ). Observed deficits in contextual learning are likely due to impaired signaling mechanisms that are required for normal synaptic plasticity and long-term hippocampal-dependent associative learning.

Previous studies have identified mild impairments in spatial learning in mice deficient in ApoER2, KO mice (Beffert et al.,
2006), or mice expressing an ApoER2 isoform that lacks exon 19 (Beffert et al., 2005), but not in the heterozygous reeler model (Qiu et al., 2006b). To determine whether Dab1 plays a role in this form of learning, WT and Dab1 cKO mice were trained in the hidden platform water maze task. Specifically, mice were trained to find a submerged platform in a circular pool filled with opaque water using distal visual cues positioned outside the pool. Training took place over the course of $4 \mathrm{~d}$ with four trials per day and an approximate intertrial interval of $1 \mathrm{~h}$. No differences were seen in latency to find the platform across training (Fig. $8 F$ ). Spatial memory was assessed using a $24 \mathrm{~h}$ probe test in which the platform was removed and mice were allowed to employ spatial search strategies to locate the platform's original location. No significant differences were seen in the distance traveled (or swim speed; data not shown). Both WT and Dabl cKO mice were similar in that they crossed over the location of the target platform significantly more times than other platform areas (Fig. 
$8 G$ ). However, a probe trial conducted $72 \mathrm{~h}$ after training revealed significant differences between $\mathrm{WT}$ and cKO mice. At this time, WT mice showed a marked preference for the target platform versus other platform areas $(p<0.05)$, whereas Dab1 cKO did not (Fig. $8 H$ ). This defect was not due to differences in total distance traveled (Fig. $8 I ; p>0.05$ ) or swim speed (data not shown). The observation that $\mathrm{cKO}$ had normal spatial memory at $24 \mathrm{~h}$, but not at $72 \mathrm{~h}$ after training, suggests that Dab1 is required for proper long-term memory consolidation.

\section{Discussion}

A multitude of studies have established the essential role of the Reelin-Dab1 signaling pathway in brain development. Using a novel genetic model, in this study we conclusively demonstrate that Reelin-Dab1 signaling is also required for adult brain function. We show that loss of Dab1 in excitatory neurons of the adult forebrain leads to a reduction in dendritic spine size, suppression of Akt and ERK signaling pathways, loss of hippocampal LTP, and ultimately deficits in hippocampal-dependent learning and memory without affecting cellular layering or dendrite morphology. Our findings may prove significant for understanding and treating neuropsychiatric and neuropathological disorders associated with reduced Reelin signaling, including schizophrenia (Guidotti et al., 2000; Verbrugghe et al., 2012), autism (Fatemi et al., 2005; Ashley-Koch et al., 2007), and Alzheimer's disease (Chin et al., 2007; Herring et al., 2012).

In agreement with previous reports (Alcántara et al., 1998; Trommsdorff et al., 1999), we observed a dramatic downregulation of Reelin and its signaling machinery that paralleled the completion of postnatal synaptic development and the transition into mature neuronal circuitry (Fig. 1). In the adult forebrain, scattered Reelin-expressing interneurons were mostly juxtaposed to Dab1-positive excitatory neurons. However, our cKO strategy also revealed that Dab1 is expressed by a subset of GABAergic interneurons (Fig. 3), suggesting that Reelin signaling onto interneurons may be important for the proper function of neural networks in the adult hippocampus. In particular, the observed enrichment of Dab1 at perisomatic synapses in the pyramidal layer suggests that Dab1 is expressed by GABAergic basket cells, which are critical regulators of hippocampal network oscillations (Klausberger, 2009). Considering that hippocampal pyramidal neurons of adult reeler heterozygous mice have reduced spontaneous IPSPs (Qiu et al., 2006b), but normal EPSPs, these data raise the possibility that the inhibitory synapse is an important site of Reelin activity that has been understudied so far. Consistent with this view, our immunofluorescence data indicate that Dab1 colocalizes frequently with the presynaptic marker synaptophysin, but less frequently with the excitatory postsynaptic marker PSD-95 in the s.r. of area CA1 (Fig. 2). Biochemical fractionation data confirmed that Dab1 is expressed both presynaptically and postsynaptically, even though it does not appear to be enriched at the synapse (Fig. 2). Dab1 was distributed in many cellular compartments, including the soma, proximal, and distal apical dendrites of hippocampal excitatory and inhibitory neurons. Overall, the pattern of Dab1 expression in the adult forebrain is consistent with the proposed role of Reelin signaling in synaptic function.

The dramatic loss of Dab1 in the adult forebrain of our cKO mice did not result in detectable changes in brain morphology, neuronal lamination, neuronal orientation, or dendritic arborization (Figs. 3, 4). We further show that Dab1 is not required for dendritic spine formation, maintenance, or molecular composition in the adult hippocampus, but is required for mature spine morphology (Fig. 4). We previously reported that reduced Reelin signaling in juvenile heterozygous reeler or Dab1 KO mice leads to a reduction in dendritic spine density in the hippocampus (Niu et al., 2008). Recent findings further demonstrated that spinogenesis and long-term synaptic plasticity are impaired in the prefrontal cortex of juvenile heterozygous reeler mice (Iafrati et al., 2013). Based on these findings, we predict that there is a postnatal window during which Reelin signaling promotes spinogenesis. Despite unaltered spine density, we observed a reduction in the cross-sectional area of dendritic spines in the adult Dab1 cKO hippocampus. This finding is consistent with the complementary discovery that Reelin overexpression in the adult hippocampus induces dendritic spine hypertrophy (Pujadas et al., 2010). This morphological phenotype may result from a chronic reduction in synaptic activity, which promotes the enlargement of dendritic spines through AMPA receptor insertion (Fortin et al., 2010; Hill and Zito, 2013). Consistent with this view, our previous work demonstrated that Reelin facilitates the insertion of AMPAR in hippocampal neurons via Dab1-dependent activation of PI3K/Akt (Qiu et al., 2006a). The reduction in spine size may also result from a persistent deficit in synaptic plasticity, which normally leads to a large postsynaptic increase in calcium that facilitates actin branching and polymerization, generating a protrusive force that facilitates spine enlargement (Fukazawa et al., 2003). Indeed, Reelin signaling promotes the activation of NMDARs through tyrosine phosphorylation of the NR2A and NR2B cytoplasmic tails, leading to increased calcium influx (Chen et al., 2005). Combined, these mechanisms could explain the observed changes in spine morphology in the Dab1 cKO mice; however, potential direct effects of Reelin on the actin cytoskeleton, as seen during development (Krüger et al., 2010), cannot be presently excluded. Given that spine morphology represents a continuum of different shapes, in this study we did not conduct a classification of different spine subtypes. We focused on spine head size, rather than neck length, as this parameter better correlates with PSD size and synaptic strength (Arellano et al., 2007). However, further analysis will be required to conclusively determine whether spine head size reduction is the only morphological anomaly present in Dab1 cKO mice.

While investigating potential signaling mechanisms underlying the spine morphology phenotype of Dabl cKO mice, we noted basal reductions in the activation of Akt and ERK1/2 pathways (Fig. 5). Both of these signal transduction pathways are activated by acute Reelin treatment of dissociated neurons. Specifically, Reelin was first shown to induce Akt phosphorylation and to promote the interaction between Dab1 and the PI3K regulatory subunit p $85 \alpha$ (Beffert et al., 2002; Ballif et al., 2003; Bock et al., 2003). Moreover, Reelin was shown to stimulate the activation of ERK1/2 in cortical neurons in a manner that depends on SFK and PI3K/Akt activation (Simó et al., 2007). While the activation of Akt and downstream signaling proteins has been confirmed in several studies (Ballif et al., 2003; Jossin and Goffinet, 2007; Ventruti et al., 2011), the stimulation of ERK1/2 phosphorylation has not yet been replicated, possibly due to differences in the composition of the Reelin conditioned medium (Ballif et al., 2003). Given our present findings that ERK1/2 phosphorylation is altered in Dab1 cKO mice, the involvement of ERK1/2 in downstream Reelin signaling warrants further investigation.

In the adult brain, both the PI3K/Akt and ERK pathways perform indispensible roles in regulating neuronal survival, synaptic plasticity, and learning and memory (Curtis and Finkbeiner, 1999; Orban et al., 1999; Sweatt, 2004). Our observed reduction in the basal activation of both Akt and ERK1/2 in Dab1 cKO mice 
in mature, but not young adult cKO mice, suggests a cumulative defect that results from chronic deficiency in Reelin signaling. Alternatively, it could be due to a sustained impairment in synaptic function or plasticity resulting from Dab1 loss at the synapse. Interestingly, we found that Dab1 loss in the adult hippocampus altered the kinetics of ERK1/2 activation following synaptic potentiation (Fig. 6). These findings implicate Dab1 as an important modulator of intracellular signaling underlying synaptic plasticity.

The present study demonstrates that Dab1 plays an important role in adult synaptic physiology. We observed reduced PPF in Dab1 cKO hippocampal slices (Fig. 7), which is consistent with previous studies using Reelin or ApoER2 mutants (Beffert et al., 2006; Qiu et al., 2006b), and suggests that Reelin signaling regulates presynaptic mechanisms controlling neurotransmitter release and short-term synaptic plasticity. Indeed, specific deficits in neurotransmission have been noted in reeler mice (Qiu et al., 2006b; Hellwig et al., 2011). However, since we did not observe extensive deletion of Dab1 in area CA3 (Fig. 3), it is possible that altered postsynaptic signaling may drive the observed presynaptic impairments. Dabl cKO mice also exhibited impairments in long-term synaptic plasticity, similar to heterozygous reeler mice (Qiu et al., 2006b) and ApoER2/VLDLR mutants (Weeber et al., 2002; Beffert et al., 2005). Unlike these previous studies, our present findings reveal physiological defects resulting from the complete loss of Reelin signaling in the adult hippocampus. Loss of Dab1 led to a profound reduction in LTP induced by HFS and TBS, and lack of LTP enhancement by Reelin. Whether the effects of Dab1 loss result exclusively from the absence of Reelin signaling, or from the disruption of other Reelin-independent signaling mechanisms in which Dab1 participates, remains to be determined.

Finally, here we demonstrated that Dab1 is required for normal hippocampal-dependent associative learning. Specifically, we observed selective hippocampal-dependent fear associative learning deficits in Dabl cKO mice, which is consistent with previous studies of heterozygous reeler mice (Qiu et al., 2006b) and ApoER2 mutants (Weeber et al., 2002; Beffert et al., 2005). Observed deficits in spatial memory in the hidden platform water maze at $72 \mathrm{~h}$, but not $24 \mathrm{~h}$, also suggests that Reelin signaling may play a role in long-term memory consolidation. In summary, our data provide the first definitive evidence that Reelin signaling through Dab1 continues to play an important role in the adult brain by regulating synaptic function and associative learning. These results will serve as a foundation upon which more detailed biochemical and physiological experiments will be designed to understand how Reelin signaling regulates synaptic function in the adult brain and how its disruption may contribute to cognitive disorders.

\section{References}

Alcántara S, Ruiz M, D’Arcangelo G, Ezan F, de Lecea L, Curran T, Sotelo C, Soriano E (1998) Regional and cellular patterns of reelin mRNA expression in the forebrain of the developing and adult mouse. J Neurosci 18: 7779-7799. Medline

Arellano JI, Benavides-Piccione R, Defelipe J, Yuste R (2007) Ultrastructure of dendritic spines: correlation between synaptic and spine morphologies. Front Neurosci 1:131-143. CrossRef Medline

Ashley-Koch AE, Jaworski J, Ma de Q, Mei H, Ritchie MD, Skaar DA, Robert Delong G, Worley G, Abramson RK, Wright HH, Cuccaro ML, Gilbert JR, Martin ER, Pericak-Vance MA (2007) Investigation of potential genegene interactions between APOE and RELN contributing to autism risk. Psychiatr Genet 17:221-226. CrossRef Medline

Ballif BA, Arnaud L, Cooper JA (2003) Tyrosine phosphorylation of
Disabled-1 is essential for Reelin-stimulated activation of Akt and Src family kinases. Brain Res Mol Brain Res 117:152-159. CrossRef Medline Beffert U, Morfini G, Bock HH, Reyna H, Brady ST, Herz J (2002) Reelinmediated signaling locally regulates protein kinase B/Akt and glycogen synthase kinase 3beta. J Biol Chem 277:49958-49964. CrossRef Medline

Beffert U, Weeber EJ, Durudas A, Qiu S, Masiulis I, Sweatt JD, Li WP, Adelmann G, Frotscher M, Hammer RE, Herz J (2005) Modulation of synaptic plasticity and memory by Reelin involves differential splicing of the lipoprotein receptor ApoER2. Neuron 47:567-579. CrossRef Medline

Beffert U, Durudas A, Weeber EJ, Stolt PC, Giehl KM, Sweatt JD, Hammer RE, Herz J (2006) Functional dissection of Reelin signaling by sitedirected disruption of Disabled-1 adaptor binding to apolipoprotein $\mathrm{E}$ receptor 2: distinct roles in development and synaptic plasticity. J Neurosci 26:2041-2052. CrossRef Medline

Bock HH, Jossin Y, Liu P, Förster E, May P, Goffinet AM, Herz J (2003) Phosphatidylinositol 3-kinase interacts with the adaptor protein Dab1 in response to Reelin signaling and is required for normal cortical lamination. J Biol Chem 278:38772-38779. CrossRef Medline

Borrell V, Pujadas L, Simó S, Durà D, Solé M, Cooper JA, Del Río JA, Soriano E (2007) Reelin and mDab1 regulate the development of hippocampal connections. Mol Cell Neurosci 36:158-173. CrossRef Medline

Campo CG, Sinagra M, Verrier D, Manzoni OJ, Chavis P (2009) Reelin secreted by GABAergic neurons regulates glutamate receptor homeostasis. PLoS One 4:e5505. CrossRef Medline

Chen K, Ochalski PG, Tran TS, Sahir N, Schubert M, Pramatarova A, Howell BW (2004) Interaction between Dabl and CrkII is promoted by Reelin signaling. J Cell Sci 117:4527-4536. CrossRef Medline

Chen Y, Beffert U, Ertunc M, Tang TS, Kavalali ET, Bezprozvanny I, Herz J (2005) Reelin modulates NMDA receptor activity in cortical neurons. J Neurosci 25:8209-8216. CrossRef Medline

Chin J, Massaro CM, Palop JJ, Thwin MT, Yu GQ, Bien-Ly N, Bender A, Mucke L (2007) Reelin depletion in the entorhinal cortex of human amyloid precursor protein transgenic mice and humans with Alzheimer's disease. J Neurosci 27:2727-2733. CrossRef Medline

Cuesto G, Enriquez-Barreto L, Caramés C, Cantarero M, Gasull X, Sandi C, Ferrús A, Acebes Á, Morales M (2011) Phosphoinositide-3-kinase activation controls synaptogenesis and spinogenesis in hippocampal neurons. J Neurosci 31:2721-2733. CrossRef Medline

Curtis J, Finkbeiner S (1999) Sending signals from the synapse to the nucleus: possible roles for CaMK, Ras/ERK, and SAPK pathways in the regulation of synaptic plasticity and neuronal growth. J Neurosci Res 58:88-95. CrossRef Medline

D'Arcangelo G (2005) The reeler mouse: anatomy of a mutant. Int Rev Neurobiol 17:383-417. Medline

D’Arcangelo G, Miao GG, Chen SC, Soares HD, Morgan JI, Curran T (1995) A protein related to extracellular matrix proteins deleted in the mouse mutant reeler. Nature 374:719-723. CrossRef Medline

D'Arcangelo G, Homayouni R, Keshvara L, Rice DS, Sheldon M, Curran T (1999) Reelin is a ligand for lipoprotein receptors. Neuron 24:471-479. CrossRef Medline

Del Río JA, Heimrich B, Borrell V, Förster E, Drakew A, Alcántara S, Nakajima K, Miyata T, Ogawa M, Mikoshiba K, Derer P, Frotscher M, Soriano E (1997) A role for Cajal-Retzius cells and reelin in the development of hippocampal connections. Nature 385:70-74. CrossRef Medline

Dragatsis I, Zeitlin S (2000) CaMKIIalpha-Cre transgene expression and recombination patterns in the mouse brain. Genesis 26:133-135. CrossRef Medline

Dumanis SB, Cha HJ, Song JM, Trotter JH, Spitzer M, Lee JY, Weeber EJ, Turner RS, Pak DT, Rebeck GW, Hoe HS (2011) ApoE receptor 2 regulates synapse and dendritic spine formation. PLoS One 6:e17203. CrossRef Medline

El Gaamouch F, Buisson A, Moustié O, Lemieux M, Labrecque S, Bontempi B, De Koninck P, Nicole O (2012) Interaction between alphaCaMKII and GluN2B controls ERK-dependent plasticity. J Neurosci 32:1076710779. CrossRef Medline

Fatemi SH, Snow AV, Stary JM, Araghi-Niknam M, Reutiman TJ, Lee S, Brooks AI, Pearce DA (2005) Reelin signaling is impaired in autism. Biol Psychiatry 57:777-787. CrossRef Medline

Fortin DA, Davare MA, Srivastava T, Brady JD, Nygaard S, Derkach VA, Soderling TR (2010) Long-term potentiation-dependent spine enlargement requires synaptic Ca2+-permeable AMPA receptors recruited by CaM-kinase I. J Neurosci 30:11565-11575. CrossRef Medline 
Franco SJ, Martinez-Garay I, Gil-Sanz C, Harkins-Perry SR, Müller U (2011) Reelin regulates cadherin function via Dab1/Rap1 to control neuronal migration and lamination in the neocortex. Neuron 69:482-497. CrossRef Medline

Fukazawa Y, Saitoh Y, Ozawa F, Ohta Y, Mizuno K, Inokuchi K (2003) Hippocampal LTP is accompanied by enhanced F-actin content within the dendritic spine that is essential for late LTP maintenance in vivo. Neuron 38:447-460. CrossRef Medline

Gobert D, Topolnik L, Azzi M, Huang L, Badeaux F, Desgroseillers L, Sossin WS, Lacaille JC (2008) Forskolin induction of late-LTP and upregulation of $5^{\prime}$ TOP mRNAs translation via mTOR, ERK, and PI3K in hippocampal pyramidal cells. J Neurochem 106:1160-1174. CrossRef Medline

Goldin M, Segal M (2003) Protein kinase C and ERK involvement in dendritic spine plasticity in cultured rodent hippocampal neurons. Eur J Neurosci 17:2529-2539. CrossRef Medline

Groc L, Choquet D, Stephenson FA, Verrier D, Manzoni OJ, Chavis P (2007) NMDA receptor surface trafficking and synaptic subunit composition are developmentally regulated by the extracellular matrix protein Reelin. J Neurosci 27:10165-10175. CrossRef Medline

Guidotti A, Auta J, Davis JM, Di-Giorgi-Gerevini V, Dwivedi Y, Grayson DR, Impagnatiello F, Pandey G, Pesold C, Sharma R, Uzunov D, Costa E, DiGiorgi Gerevini V (2000) Decrease in reelin and glutamic acid decarboxylase67 (GAD67) expression in schizophrenia and bipolar disorder: a postmortem brain study. Arch Gen Psychiatry 57:1061-1069. CrossRef Medline

Hanse E, Gustafsson B (1994) TEA elicits two distinct potentiations of synaptic transmission in the CA1 region of the hippocampal slice. J Neurosci 14:5028-5034. Medline

Hayashi Y, Majewska AK (2005) Dendritic spine geometry: functional implication and regulation. Neuron 46:529-532. CrossRef Medline

Heinrich C, Nitta N, Flubacher A, Müller M, Fahrner A, Kirsch M, Freiman T, Suzuki F, Depaulis A, Frotscher M, Haas CA (2006) Reelin deficiency and displacement of mature neurons, but not neurogenesis, underlie the formation of granule cell dispersion in the epileptic hippocampus. J Neurosci 26:4701-4713. CrossRef Medline

Hellwig S, Hack I, Kowalski J, Brunne B, Jarowyj J, Unger A, Bock HH, Junghans D, Frotscher M (2011) Role for Reelin in neurotransmitter release. J Neurosci 31:2352-2360. CrossRef Medline

Herring A, Donath A, Steiner KM, Widera MP, Hamzehian S, Kanakis D, Kölble K, ElAli A, Hermann DM, Paulus W, Keyvani K (2012) Reelin depletion is an early phenomenon of Alzheimer's pathology. J Alzheimers Dis 30:963-979. Medline

Hiesberger T, Trommsdorff M, Howell BW, Goffinet A, Mumby MC, Cooper JA, Herz J (1999) Direct binding of Reelin to VLDL receptor and ApoE receptor 2 induces tyrosine phosphorylation of disabled-1 and modulates tau phosphorylation. Neuron 24:481-489. CrossRef Medline

Hill TC, Zito K (2013) LTP-induced long-term stabilization of individual nascent dendritic spines. J Neurosci 33:678-686. CrossRef Medline

Hoe HS, Fu Z, Makarova A, Lee JY, Lu C, Feng L, Pajoohesh-Ganji A, Matsuoka Y, Hyman BT, Ehlers MD, Vicini S, Pak DT, Rebeck GW (2009) The effects of amyloid precursor protein on postsynaptic composition and activity. J Biol Chem 284:8495-8506. Medline

Howell BW, Hawkes R, Soriano P, Cooper JA (1997) Neuronal position in the developing brain is regulated by mouse disabled-1. Nature 389:733737. CrossRef Medline

Howell BW, Herrick TM, Cooper JA (1999) Reelin-induced tyrosine [corrected] phosphorylation of disabled 1 during neuronal positioning. Genes Dev 13:643-648. CrossRef Medline

Howell BW, Herrick TM, Hildebrand JD, Zhang Y, Cooper JA (2000) Dab1 tyrosine phosphorylation sites relay positional signals during mouse brain development. Curr Biol 10:877-885. CrossRef Medline

Iafrati J, Orejarena MJ, Lassalle O, Bouamrane L, Chavis P (2013) Reelin, an extracellular matrix protein linked to early onset psychiatric diseases, drives postnatal development of the prefrontal cortex via GluN2BNMDARs and the mTOR pathway. Mol Psychiatry. Advance online publication. Retrieved Jun 11, 2013. doi:10.1038/mp.2013.66. CrossRef

Jossin Y, Cooper JA (2011) Reelin, Rap1 and N-cadherin orient the migration of multipolar neurons in the developing neocortex. Nat Neurosci 14:697-703. CrossRef Medline

Jossin Y, Goffinet AM (2007) Reelin signals through phosphatidylinositol 3-kinase and Akt to control cortical development and through mTor to regulate dendritic growth. Mol Cell Biol 27:7113-7124. CrossRef Medline

Karson MA, Tang AH, Milner TA, Alger BE (2009) Synaptic cross talk between perisomatic-targeting interneuron classes expressing cholecystokinin and parvalbumin in hippocampus. J Neurosci 29:4140-4154. CrossRef Medline

Klausberger T (2009) GABAergic interneurons targeting dendrites of pyramidal cells in the CA1 area of the hippocampus. Eur J Neurosci 30:947957. CrossRef Medline

Krueger DD, Howell JL, Hebert BF, Olausson P, Taylor JR, Nairn AC (2006) Assessment of cognitive function in the heterozygous reeler mouse. Psychopharmacology 189:95-104. CrossRef Medline

Krüger MT, Zhao S, Chai X, Brunne B, Bouché E, Bock HH, Frotscher M (2010) Role for Reelin-induced cofilin phosphorylation in the assembly of sympathetic preganglionic neurons in the murine intermediolateral column. Eur J Neurosci 32:1611-1617. CrossRef Medline

Liu WS, Pesold C, Rodriguez MA, Carboni G, Auta J, Lacor P, Larson J, Condie BG, Guidotti A, Costa E (2001) Down-regulation of dendritic spine and glutamic acid decarboxylase 67 expressions in the reelin haploinsufficient heterozygous reeler mouse. Proc Natl Acad Sci U S A 98: 3477-3482. CrossRef Medline

Maharana C, Sharma KP, Sharma SK (2013) Feedback mechanism in depolarization-induced sustained activation of extracellular signalregulated kinase in the hippocampus. Sci Rep 3:1103. Medline

Majumdar D, Nebhan CA, Hu L, Anderson B, Webb DJ (2011) An APPL1/ Akt signaling complex regulates dendritic spine and synapse formation in hippocampal neurons. Mol Cell Neurosci 46:633-644. CrossRef Medline

Matsuzaki M, Ellis-Davies GC, Nemoto T, Miyashita Y, Iino M, Kasai H (2001) Dendritic spine geometry is critical for AMPA receptor expression in hippocampal CA1 pyramidal neurons. Nat Neurosci 4:10861092. CrossRef Medline

Matsuzaki M, Honkura N, Ellis-Davies GC, Kasai H (2004) Structural basis of long-term potentiation in single dendritic spines. Nature 429:761-766. CrossRef Medline

Niu S, Renfro A, Quattrocchi CC, Sheldon M, D'Arcangelo G (2004) Reelin promotes hippocampal dendrite development through the VLDLR/ ApoER2-Dab1 pathway. Neuron 41:71-84. CrossRef Medline

Niu S, Yabut O, D'Arcangelo G (2008) The Reelin signaling pathway promotes dendritic spine development in hippocampal neurons. J Neurosci 28:10339-10348. CrossRef Medline

O'Dell RS, Ustine CJ, Cameron DA, Lawless SM, Williams RM, Zipfel WR, Olson EC (2012) Layer 6 cortical neurons require Reelin-Dab1 signaling for cellular orientation, Golgi deployment, and directed neurite growth into the marginal zone. Neural Dev 7:25. CrossRef Medline

Ogawa M, Miyata T, Nakajima K, Yagyu K, Seike M, Ikenaka K, Yamamoto H, Mikoshiba K (1995) The Reeler gene-associated antigen on CajalRetzius neurons is a crucial molecule for laminar organization of corticalneurons. Neuron 14:899-912. CrossRef Medline

Orban PC, Chapman PF, Brambilla R (1999) Is the Ras-MAPK signalling pathway necessary for long-term memory formation? Trends Neurosci 22:38-44. CrossRef Medline

Park TJ, Curran T (2008) Crk and Crk-like play essential overlapping roles downstream of Disabled-1 in the Reelin pathway. J Neurosci 28:1355113562. CrossRef Medline

Pesold C, Impagnatiello F, Pisu MG, Uzunov DP, Costa E, Guidotti A, Caruncho HJ (1998) Reelin is preferentially expressed in neurons synthesizing gamma-aminobutyric acid in cortex and hippocampus of adult rats. Proc Natl Acad Sci U S A 95:3221-3226. CrossRef Medline

Pujadas L, Gruart A, Bosch C, Delgado L, Teixeira CM, Rossi D, de Lecea L, Martínez A, Delgado-García JM, Soriano E (2010) Reelin regulates postnatal neurogenesis and enhances spine hypertrophy and long-term potentiation. J Neurosci 30:4636-4649. CrossRef Medline

Qiu S, Weeber EJ (2007) Reelin signaling facilitates maturation of CA1 glutamatergic synapses. J Neurophysiol 97:2312-2321. CrossRef Medline

Qiu S, Zhao LF, Korwek KM, Weeber EJ (2006a) Differential reelin-induced enhancement of NMDA and AMPA receptor activity in the adult hippocampus. J Neurosci 26:12943-12955. CrossRef Medline

Qiu S, Korwek KM, Pratt-Davis AR, Peters M, Bergman MY, Weeber EJ (2006b) Cognitive disruption and altered hippocampus synaptic function in Reelin haploinsufficient mice. Neurobiol Learn Mem 85:228-242. CrossRef Medline

Rice DS, Sheldon M, D’Arcangelo G, Nakajima K, Goldowitz D, Curran T 
(1998) Disabled-1 acts downstream of Reelin in a signaling pathway that controls laminar organization in the mammalian brain. Development 125:3719-3729. Medline

Rogers JT, Rusiana I, Trotter J, Zhao L, Donaldson E, Pak DT, Babus LW, Peters M, Banko JL, Chavis P, Rebeck GW, Hoe HS, Weeber EJ (2011) Reelin supplementation enhances cognitive ability, synaptic plasticity, and dendritic spine density. Learn Mem 18:558-564. CrossRef Medline

Sekine K, Kawauchi T, Kubo K, Honda T, Herz J, Hattori M, Kinashi T, Nakajima K (2012) Reelin controls neuronal positioning by promoting cell-matrix adhesion via inside-out activation of integrin alpha 5 beta 1 . Neuron 76:353-369. CrossRef Medline

Sheldon M, Rice DS, D’Arcangelo G, Yoneshima H, Nakajima K, Mikoshiba K, Howell BW, Cooper JA, Goldowitz D, Curran T (1997) Scrambler and yotari disrupt the disabled gene and produce a reeler-like phenotype in mice. Nature 389:730-733. CrossRef Medline

Sík A, Hájos N, Gulácsi A, Mody I, Freund TF (1998) The absence of a major $\mathrm{Ca} 2+$ signaling pathway in GABAergic neurons of the hippocampus. Proc Natl Acad Sci U S A 95:3245-3250. CrossRef Medline

Simó S, Pujadas L, Segura MF, La Torre A, Del Río JA, Ureña JM, Comella JX, Soriano E (2007) Reelin induces the detachment of postnatal subventricular zone cells and the expression of the Egr-1 through Erk1/2 activation. Cereb Cortex 17:294-303. Medline

Sweatt JD (2004) Mitogen-activated protein kinases in synaptic plasticity and memory. Curr Opin Neurobiol 14:311-317. CrossRef Medline

Trommsdorff M, Gotthardt M, Hiesberger T, Shelton J, Stockinger W, Nimpf J, Hammer RE, Richardson JA, Herz J (1999) Reeler/disabled-like disruption of neuronal migration in knockout mice lacking the VLDL receptor and ApoE receptor 2. Cell 97:689-701. CrossRef Medline
Trotter JH, Klein M, Jinwal UK, Abisambra JF, Dickey CA, Tharkur J, Masiulis I, Ding J, Locke KG, Rickman CB, Birch DG, Weeber EJ, Herz J (2011) ApoER2 function in the establishment and maintenance of retinal synaptic connectivity. J Neurosci 31:14413-14423. CrossRef Medline

Tsien JZ, Chen DF, Gerber D, Tom C, Mercer EH, Anderson DJ, Mayford M, Kandel ER, Tonegawa S (1996) Subregion- and cell type-restricted gene knockout in mouse brain. Cell 87:1317-1326. CrossRef Medline

Tsokas P, Ma T, Iyengar R, Landau EM, Blitzer RD (2007) Mitogenactivated protein kinase upregulates the dendritic translation machinery in long-term potentiation by controlling the mammalian target of rapamycin pathway. J Neurosci 27:5885-5894. CrossRef Medline

Ventruti A, Kazdoba TM, Niu S, D’Arcangelo G (2011) Reelin deficiency causes specific defects in the molecular composition of the synapses in the adult brain. Neuroscience 189:32-42. CrossRef Medline

Verbrugghe P, Bouwer S, Wiltshire S, Carter K, Chandler D, Cooper M, Morar B, Razif MF, Henders A, Badcock JC, Dragovic M, Carr V, Almeida OP, Flicker L, Montgomery G, Jablensky A, Kalaydjieva L (2012) Impact of the Reelin signaling cascade (ligands-receptors-adaptor complex) on cognition in schizophrenia. Am J Med Genet B Neuropsychiatr Genet 159B:392-404. CrossRef Medline

Weeber EJ, Beffert U, Jones C, Christian JM, Forster E, Sweatt JD, Herz J (2002) Reelin and ApoE receptors cooperate to enhance hippocampal synaptic plasticity and learning. J Biol Chem 277:39944-39952. CrossRef Medline

Wiegert JS, Bading H (2011) Activity-dependent calcium signaling and ERK-MAP kinases in neurons: a link to structural plasticity of the nucleus and gene transcription regulation. Cell Calcium 49:296-305. CrossRef Medline 